\title{
A Bibliometric Analysis of Health and Medical Journals: Issues in Medical Scholarly Communication in Africa
}

\section{Ifeanyi J. Ezema \& Omwoyo Bosire Onyancha}

To cite this article: Ifeanyi J. Ezema \& Omwoyo Bosire Onyancha (2016): A Bibliometric Analysis of Health and Medical Journals: Issues in Medical Scholarly Communication in Africa, Serials Review, DOI: $10.1080 / 00987913.2016 .1182881$

To link to this article: http://dx.doi.org/10.1080/00987913.2016.1182881

Accepted author version posted online: 05

May 2016.

Submit your article to this journal $\sqsubset$

a)

View related articles $\sqsubset$

View Crossmark data $₫$ 


\title{
ACCEPTED MANUSCRIPT
}

Title: A Bibliometric Analysis of Health and Medical Journals: Issues in Medical Scholarly Communication in Africa

\author{
Authors \\ Ifeanyi J. Ezema \\ Nnamdi Azikiwe Library, University of Nigeria, Nsukka, Nigeria \\ Post-doctoral research Fellow, University of South Africa, Department of Information Science \\ E-mail: ezemaji@unisa.ac.za ifeanyi.ezema@unn.edu.ng \\ Omwoyo Bosire Onyancha \\ University of South Africa, Department of Information Science, Unisa, \\ E-mail: onyanob@unisa.ac.za
}

\begin{abstract}
The study was conducted to examine the scholarly impact of health and medical journals in Africa. A descriptive informetric research approach was used to analyse 134 health and medical journals hosted in the African Journal Online (AJOL) database. Harzing's Publish or Perish (PoP) software was used to extract publication and citation indicators of the journals. These indicators include number of citations, number of paper publications, cites per year, cites per paper, and the h-index of the journals. The performance of the journals was equally examined in other major databases like Thomson Reuters and Scopus. Findings reveal that only 20 African countries contributed health and medical journals to the AJOL database with Nigeria and South
\end{abstract}




\section{ACCEPTED MANUSCRIPT}

Africa producing nearly $70 \%$ of the journals. A rank list of 29 journals was developed with South African Medical Journal and African Health Sciences ranking highest in the list respectively. Only 14 of the journals were found in Thompson Reuters while Scopus indexes only $38.8 \%$ of the journals. These findings challenge the criteria Thompson Reuters and Scopus use in the selection of journals for their databases.

Keywords: Bibliometrics, informetrics, citation analysis, health research, journal evaluation, health and medical journals, Africa 


\section{ACCEPTED MANUSCRIPT}

\section{Introduction}

Quality health and medical services are critical indicators of the socioeconomic and scientific development of any nation. Consequently, many development plans give priority to ensuring that citizens receive good health services. However, improved medical and health services are usually propelled by the amount and quality of research conducted in the area. Evidence abounds that Africa has one of the worst developed health systems in the world, as it performs poorly in major health indictors compared to other regions (WHO, 2014; WHO, 2015; World Bank, 2015). For instance, the 2015 World Development Indicators shows that major indicators of good health and general wellbeing such as maternal and child mortality, HIV/AIDS prevalence, preventable communicable diseases, degenerative diseases, and poor nutrition are high in sub-Saharan Africa when compared with other regions (World Bank, 2015). The implication is that there is a need for a substantial increase in health and medical research by African researchers with focus on the region's health challenges particularly tropical diseases. This has been underscored by Pang, Sadana, Hanney, Bhutta, Hyder and Simon (2003), and its importance in the generation of scientific knowledge has been noted by Lee (2003). Literature is replete with Africa's low research productivity (Olukoju, 2004; Lor, 2007; Bako, 2005; Ezema, 2010, Ezeh, Izugbara, Kabiru, Fonn, Kahn, Manderson, Undieh, Omigbodum \& Thorogood 2010; Gailard, 2010). Mouton's (2010) study has shown a decline of African publications in the ISI Web of Science, while a recent study by Ioannids, Boyack and Klavans (2014) posits that $42 \%$ of the global scientific research outputs from 1996 to 2011 were generated by less than $1 \%$ of the global scientific community. A large proportion of the overall global scientific productivity is not always relevant to the African sub-region due to the transatlantic divide in research publications 


\section{ACCEPTED MANUSCRIPT}

(Falagas, Karavasia \& Bliziotis, 2006). Apparently, research reports from Africa are poorly disseminated resulting in a lack of visibility in the international scholarly community (Ezema, 2011). Hence Nwagwu (2006) had earlier proposed a scholarly database for international visibility of African research productivity. In continuation of this position, Nwagwu \& Onyancha (2015) have argued for the democratisation of research dissemination where scientists would be free to disseminate research products without the journal for enhanced universal availability of scientific outputs.

Usually, research evaluation metrics are useful indicators for determining research productivity and its impact in the global scientific community. The studies are usually conducted using source data from journals, theses, and dissertations among other scholarly communication channels. Bibliometric studies are generally used to evaluate the research productivity of a geographical area, institution, journals, or an individual author. This has been applied in health and medical journals to determine productivity in HIV/AIDS (Onyancha, 2008; Rosas et Al, 2011), biomedical research in Nigeria (Nwagwu, 2005 and 2006), tropical medicine research (Falagas, Karavasiou \& Bliziotis, 2006; Smith, 2008), cardiovascular disease research (Rosmarakis et al, 2005), chronic obstructive pulmonary diseases (Gu, Yuan, Yang, Qi, Jin, Yan, 2015), homeopathy research productivity (Chiu \& Ho, 2005), and preventive, occupational, environmental medicine and public health (Smith, 2010). It has also been applied in evaluation of health and medical research in some countries such as Nepal (Simkhada, Baral \& Teijlingen, 2010), Kenya, and South Africa (Onyancha \& Ocholla, 2007). Bibliometric analyses of health and medical-related subjects has also been applied in research evaluation in academic institutions (Hendrix, 2008) and general health and medical practice as has been documented in Falagas, 


\section{ACCEPTED MANUSCRIPT}

Michalopoulos, Bliziotis and Soteriades (2006); Kim, Park, Yoo and Shen (2010); and Hsu and Ho (2014).

Many studies employ the Web of Science (WoS) database, which is recognised internationally as a key source for bibliometric data. Much as the WoS indexes several top journals in its three-pronged databases (Science Citation Index (SCI), Social Sciences Citation Index (SSCI), and Arts \& Humanities Citation Index (A\&HCI)), journal entries in the databases are skewed in favor of the advanced countries of Europe, North America and Canada since a lot of other journals, particularly in developing countries, lack presence in WoS Journal Citation Report (JCR) (Ezema, 2010). Similarly, other researchers have criticised WoS for promoting and propagating flawed and biased bibliometric data (Segel, 1997; Walter, Bloch, Hunt \& Fisher, 2003; Loonen, Hage \& Kon, 2007; Moed, 2005; Meho, 2007; Hendrix, 2008), while at the same time excluding the vast majority of other journals across the globe. Besides these arguments, the belief is that health and medical research relevant to African development is often published largely by African scholars in African journals (Fonn, 2005; Ezeh et al, 2010). For this reason, this study deviates from using Thomson Reuters (JCR) as a source of data; rather, the most popular database of African origin (i.e., African Journals Online - AJOL) was used. This database was launched in 1997 by the International Network for Availability of Scientific Publications (INASP) to provide global visibility for African research publications (Mouton, 2010). INASP was established in 1992 by the International Council for Science (ICSU) to improve access, production, and use of research information and knowledge to assist in addressing developmental challenges in many countries (see INASP website www.inasp.info). 


\section{ACCEPTED MANUSCRIPT}

Currently AJOL hosts over 500 journals from all African countries in its website/database, found at http://www.ajol.info/, with 165 of the journals in Health and Medical Sciences. This study therefore aims at using bibliometric analysis to examine research productivity in health and medical sciences using the AJOL database. The study specifically intends to do the following:

1. Determine the country-wise distribution of health and medical journals in Africa.

2. Develop a rank list of the most cited health and medical journals in research in Africa.

3. Determine the most productive health and medical journals in Africa.

4. Examine the performance of the most cited journals in other major indexing databases.

\section{Literature Review}

Research productivity (that is quantity of research outputs and their impact in the global scientific community) in Africa is an interesting area of concern among many stakeholders such as governments, institutions of higher learning, research institutes, and academics. Apart from its role in most national development agendas, research constitutes one of the instruments used in ranking institutions and countries. For example, the latest ranking of African universities by Journals Consortium (http://ranking.journalsconsortium.org/) was based on research publications found on the Internet - a large number of them published in journals.

\subsection{The need for journal evaluation}

Journals have for a long time been the major channel of communication of research reports to the global scientific community. Researchers on a daily basis generate new knowledge, which has led to an information explosion and proliferation of journals and other channels of scholarly 


\section{ACCEPTED MANUSCRIPT}

communication. Consequently, indexing and abstracting agencies spend time and funds on the bibliographic control of information emanating from journals. This, however, has given way to a huge challenge to these agencies because of the large number of journals scattered in many disciplines - some of them of high quality with international visibility and impact, and others very substandard, highly localised, and often seen by only the authors and the editors (Ezema, 2011). A recent development in journal publishing is the infiltration of predatory open access journals in the scholarly communication platform, of which Jeffrey Beall has progressively updated a list of these suspected predatory journals (Beall, 2016) and created awareness of this concern (Beall, 2015). Although controversies surround Beall's list, studies has shown that the major interest of predatory open access journals is mainly article processing charges (APC) rather than the scholarly peer review mechanism of reputable journals (Shen \& Bjork, 2015; Webster \& Butler, 2015; Christopher \& Young, 2015). As a result, funding bodies, government agencies, libraries, and researchers need reliable information regarding the quality and impact of these journals in the global scholarly community - resulting in the need for journal evaluation and ranking. Evaluation is critical in establishing the authoritativeness, objectivity, validity, reliability, comprehensiveness, and timeliness of the information source where the research is published (Kentucky Virtual Library, 2004a and 2004b). Studies on why sources of scientific information are evaluated are numerous (Onyancha, 2008b; Scott, et al, 2010). Scott et al identified three key issues of importance in bibliometric analysis, namely activity, impact, and linkage measurements, but Rousseau (2002), cited in Onyancha, (2008b: 56), summarised the relevance of journal evaluation thus: 


\section{ACCEPTED MANUSCRIPT}

- Funding agencies and governments want their grantees to publish in the most prestigious journals;

- Editors and publishers may relate high citation scores to successful editorial practice and policy;

- Commercial publishers are interested in subscription data and sale;

- Information brokers are interested in finding the sources that have the greatest potential to satisfy their clients' needs;

- University research councils use journals' impact scores and ratings of prestige as elements in local research evaluation studies, with a view to enlarging the visibility of the university research outputs.

In the evaluation and ranking of journals, different approaches, techniques, or methods are often deployed. Onyancha (2008b: 56) remarked that both bibliometric and non-bibliometric techniques are used for journal evaluation. According to him, non-bibliometric indicators include "circulation statistics, the prestige or reputation of publishing company, the number of databases indexing a given source (journal), the number of subscriptions and the corresponding amount of revenue, the number of interlibrary loan requests and peer review." Bibliometric evaluation techniques are mainly through citation studies that provide such metrics as influence weight, hindex, impact factor, and popularity factor, among other indicators. Bibliometric techniques apply quantitative analysis and statistical indicators to describe the pattern of publications and citations within a given field of study, period, geographical area, authors, institutions, and sometimes countries (Chiu \& Ho, 2005; Hendrix, 2008). Ezema \& Asogwa $(2012,2014)$ have also applied it to develop rank list of journals in veterinary medicine and linguistics. 


\section{ACCEPTED MANUSCRIPT}

\subsection{Citation analysis and journal evaluation}

Attempts to measure the impact of journals or an author in a particular field have always been a critical issue in the library and information science profession. As far back as 1927, Gross and Gross made a bold attempt to conduct a study of citation patterns in order to determine the most valuable journal in chemistry by manually counting the number of citations in the Journal of American Chemical Society and ranking them in frequency of citation (Herzel, 2003). Later, Bradford (1934) published a classic article, which was widely referred to as the law of scattering of journals where he propounded that "If scientific journals are arranged in order of decreasing productivity of articles, in a given subject, they may be divided into a nucleus of periodicals more devoted to the subject and several groups or zones containing the same number of articles as the nucleus, when the number of periodicals in the nucleus and succeeding zones will be a 1 : $\mathrm{n}: \mathrm{n}^{2}$

Citation to articles or journals is believed to determine the impact of the publication in global research communities and relatedness between scientific publications (Belter, 2015). Despite the value of citation analysis in research evaluation, there are several criticisms against its use (MacRoberts \& MacRoberts, 2006; Meho, 2007; Belter, 2015; Gu, Yuan, Yang, Qi, Jin \& Yan, 2015; Stegehuis, Litvak \& Waltman, 2015; Clough, Gollings, Loach \& Evans, 2015). Some of the major criticisms include authors citing what they have not read, self citation, currency citation bias reported by Griggs \& Christopher (2015), phenomenon of homographs that make it difficult to separate citations of two or more unrelated researchers; the problem of cronyism, where friends or related colleagues reciprocally cite each other for increased citation counts; 


\section{ACCEPTED MANUSCRIPT}

ceremonial citation, where an author may cite an authority in a field without consulting the work, and negative citation, which points out incorrect research results but still counts in favor of the document (Meho, 2007). In spite of these flaws of citation analysis, it has remained a relevant tool for journal evaluation.

2.3 Application of citation analysis in health and medical research evaluation

The need for the evaluation of health and medical research productivity is of serious concern because of the pivotal roles of adequate health and medical services in the development indicators of every country. Apart from this, Ezeh et al (2010) posited that Africa should wake up and tackle the challenges of disease burdens that are being aggravated by socioeconomic, political, and environmental changes. According to the authors, attempts in mitigating this rising disease burden in Africa require public research capacity. The belief is that knowledge generated through health research, if widely disseminated, will positively impact the performance of national, regional and global health systems (Onyeka, 2014; Hsu, Y.-H \& Ho, Y.-S. (2014). Health and medical research has a wide coverage, namely biomedical, clinical, epidemiological, health systems and policy research, socioeconomic and behavioral research, etc. (Pang, Sadana, Hanney, Bhutta, Hyder \& Simon, 2003). This wide scope is likely to be reflected in the number of journals and other publication channels of health and medical research leading to a number of studies in research evaluation in the field.

Glover \& Bowen (2004) and Schoonbaert (2004), in separate studies, examined citation patterns in tropical medicine journals and found that Europe and Africa contributed more papers and citations, with malaria, HIV/AIDS, and schistosomiasis as the most researched diseases. Another related study by Falagas, Karavasiou, and Bliziotis (2006) found that Africa produced 


\section{ACCEPTED MANUSCRIPT}

only $20.9 \%$ of the global research in tropical medicine despite the fact that it is a field of research where Africa stands to benefit most. Another bibliometric study in Nepal by Simkhada, Baral, and Van Teijlingen (2010) found that only $11 \%$ of the researches were published in Nepalese journals, but two thirds of articles are published by authors from Nepal - an indication that often publications from developing countries appear not to reach the required audience. Hsu and Ho (2014) also found that $76 \%$ of highly cited articles in health care science were published in the United States. Recent studies (Gu, Yuan, Qi, Jin \& Yan) also found that the United States, England, and Canada are leading in chronic obstructive pulmonary diseases research; while in obesity research, United State still leads (42\%), but many European and Japanese institutions ranked higher in citations and collaboration (Khan, Choundhury, Uddin, Hossain \& Baur, 2016). Another recent study by Nwagwu and Ojemeni (2015) looked at the penetration of Nigeria biomedical open access journals and found out that Nigeria, China, and India make the highest contributions of articles to the journals and citation penetration is higher from Asia and Africa. It appears there is no study that has been conducted to focus on health and medical research in Africa generally, and none has used a database of African origin, hence the need for the present study.

\section{Methods and Materials}

This study takes the form of descriptive informetrics, which Diodato (1994:15) refers to as "the collection of descriptive information about documents to provide bodies responsible for the production and transmission of information; form of transmission; medium of communication; nature of information conveyed and geographical origin.” The study used 165 health and medical 


\section{ACCEPTED MANUSCRIPT}

journals listed in the African Journals Online (AJOL) database. AJOL is the most popular database that indexes journals of African origin with strong presence in medical and health journals. The database indexes all journals in all fields of study with a web presence and emanating from Africa. Onyeka (2014) describes AJOL as a database that provides free, low cost access to research literature in Africa. After careful examination of the 165 journals, 20 of them were found not to be core health and medical journals (journals in health and physical education, counselling, undergraduate journals, etc.) and therefore were excluded from the study. The remaining 145 journals therefore constituted the target population in this study. Details of the journals used for the study are provided in Appendix 1. The journal titles were entered into the Harzing's Publish or Perish (PoP) software (Harzing, 2007) to extract relevant data for this study. The software has an inbuilt mechanism for the extraction of author, journal impact, and general citations data using Google Scholar or Microsoft Academic Search platforms. The Google Scholar platform was used to extract informetric data of the journals, namely the total number of papers, total number of citations, number of citations per paper, number of citations per year, and h-index for a five-year period (i.e., 2010 to 2014). For the purpose of this study, hindex metric was chosen to determine the research impact of the journals. Its choice was based on its popular use in research evaluation. H-index was developed by J.E Hirsch in 2005 as an index that attempts to measure both scientific productivity and impact. It is defined as "the number of papers with citation number $\geq h$, and a useful index to characterize the scientific output of a researcher (Hirsch, 2005). Of the 145 journals, 11 were not recognised by the Publish or Perish software, and therefore, no result was generated for the journals. These journals were equally excluded from the study, leaving 134 journals for the final analysis. Ulrich Global Serials 


\section{ACCEPTED MANUSCRIPT}

(http://ulrichsweb.serialssolutions.com/) was searched to determine the size of journals published in the African countries and compare them with journals found in AJOL. The search was refined using the following limiters: country of publication, subject- medicine and health, scholarly journals, and active journals. A search was also conducted using Scopus and ISI Web of Science to determine the journals' performance in these major databases when compared to Google Scholar. Microsoft Excel was used to determine the frequency distribution of the data. These searches were conducted over a week (13-20 August 2015). To generate a list of the most frequently cited medical journals, the cut-off mark for the citations was taken from journals that met the average citation of 333.3. Similarly, journals that met the average paper productivity of 190.3 were listed in the high productivity journals.

\section{Results}

This section provides the findings of the study.

\subsection{Distribution of health and medical journals by country in Africa}

Table 1 presents results of the country-wise distribution of health and medical journals in Africa. It was observed that only 20 countries contributed the 145 health and medical journals found in the AJOL database. Nigeria contributes more than half the journals in medical and health sciences with 79 (54.4\%) journal titles. This is followed by South Africa with 20 (13.8\%) journal titles while Kenya and Egypt have $9(6.2 \%)$ and 8 (5.5\%) journal titles respectively. Close observations show that proportions of medical journals in AJOL is higher than that of Ulrich for Nigeria, South Africa, Egypt, Kenya and many other countries. The overall proportion of AJOL 


\section{ACCEPTED MANUSCRIPT}

medical journals is $29.8 \%$ while Ulrich is $24.1 \%$; only $30.3 \%$ of the health and medical journals are found in AJOL database.

\section{<Insert Table 1. Country-wise distribution of health and medical journals in Africa.>}

\subsection{Citation performance of health and medical journals in Africa}

South African Medical Journal received the highest number of citations from Google Scholar. The journal received followed by African Health Sciences with an h-index of 20 and 3348 citations (see Table 2), while Kenyan journal Pan African Medical Journal has 2957 citations. Tropical Journal of Pharmaceutical Research published in Nigeria received 2611 citations. In WoS, South African Medical Journal also has the highest citations, followed by African Health Sciences and Tropical Journal of Pharmaceutical Research. South African Medical Journal remains consistent in citation counts as it also received the highest citations in Scopus followed by West African Journal of Medicine. A close observation shows that 29 (21.6\%) of the total number of journals produced a total of 37448 citations representing $83.8 \%$ of the citations received by all the journals investigated in the study. This indicates that almost one fifth of the journals are the most frequently cited, which mostly correlates with Bradford's law of the scattering of journals.

\subsection{Most productive health and medical journals in Africa}

The journal with the highest paper productivity in Google Scholar as shown is Pan African Medical Journal with 2753 papers, followed by South African Medical Journal with 1853 


\section{ACCEPTED MANUSCRIPT}

papers and the third journal is South African Family Practice with 1748 papers. In WoS, African Journal of Traditional, Complementary and Alternative Medicines, and Tropical Journal of Pharmaceutical Research produced the highest papers with 244 papers each followed by Nigerian Journal of Clinical Practice. However, in Scopus, Pan African Medical Journal produced the highest number of papers followed by South African Medical Journal and Tropical Journal of Pharmaceutical Research. The 35 most productive journals constitute $26.2 \%$ of the total journals, but produced about $71.4 \%$ of the papers (see Appendix 1). This implies that very few core journals (most productive) publish a large percentage of papers in the field, and the remaining $28.6 \%$ are scattered between several other journals, in line with Bradford's law of scattering.

Although Nigerian journals still dominate the list of top ranked journals in terms of their productivity and impact, the percentages in both productivity and citations are lower than the country's total contribution to the overall journal titles (see Table 1). This is an indication that a large proportion of Nigerian journals failed to make the list of highly productive and cited journals. South Africa contributed 9 (25.7\%) journals and 6 (20.9\%) journal titles in the lists of highly productive and cited journals respectively. Egypt has 4 journals in the list of most productive journals and 2 in the highly cited journals, while Tanzania has 2 each in both lists.

All the journals found in the AJOL database were searched within Thompson Reuters ISI to determine their performance and the findings are presented in Table 4. Indications from the search show that only 14 of the journals representing $10.2 \%$ of all the journals were found in 


\section{ACCEPTED MANUSCRIPT}

Thompson Reuters. It is important to observe that 17 of the highly productive journals are completely absent in Web of Science, while 4 journals that failed to make the list of highly productive journals in AJOL are present in WoS. This means that only $10(37 \%)$ of the highly productive journals are indexed in WoS. South Africa produced $42.8 \%$ of the journals found in WoS, while Nigeria followed with $21.4 \%$. The remaining countries - Ethiopia, Malawi, Kenya, Libya and Uganda - have $1(7.1 \%)$.

\section{<Insert Table 2. Comparative performance of the journals in major indexing databases.>}

It can be observed that 24 out of the 29 most cited journals are indexed by Scopus, while only 10 of the most productive journals could be located in Thompson Reuters JCR. It is also important to note the remarkable reduction in the number of publications and citations of the journals that appeared in the Thompson Reuters JCR. A close observation also shows that the first two ranked journals are general medical journals; but there is almost an even distribution of medical and speciality journals - $15(51.7 \%)$ as compared to $14(49.3 \%)$ speciality journals. Similarly, although international journals dominate (based on their names) the first ten high impact journals, generally there more national journals $(17,58.6 \%)$ than international journals $(12$, 41.4\%). Figure 1 shows the percentage of the journals indexed in the major databases. All the $134(100 \%)$ journals are indexed by Google Scholar while 52 (38.8\%) of the journals are indexed in Scopus and only $14(10.5 \%)$ of the journals are indexed by Thompson Reuters. It is expected that with the high citations received by many of the journals resulting in high impact (h-index) as 


\section{ACCEPTED MANUSCRIPT}

measured by Google Scholar, a large proportion of the journals would be indexed in Thomson Reuters' and Scopus databases.

<Insert Figure 1. Percentage of AJOL journals in citation databases.>

\section{Discussion, Conclusions and Recommendations}

Findings from this study provide insight about the coverage, visibility, and impact of health and medical research published in Africa and as indexed in AJOL. The country-wise distribution of health and medical journals in Africa shows that Nigeria contributes more than $50 \%$ of health and medical journals found in AJOL followed by South Africa with 13.8\%. Much as this is a reflection of earlier, separate studies of the database in (Ezema, 2010; Mounton, 2010); it is surprising that South Africa's journal contribution is still low. Perhaps this is because South Africa has a national database where journals are also indexed (SABINET South Africa), while Nigeria is yet to develop a national database for hosting as well as disseminating journals published in the country. This development calls for further study on the composition and research impact of medical journals in SABINET South Africa in relation with others in AJOL.

It is of interest, however, to observe that some countries such as Kenya, Egypt, and Tanzania make reasonable contributions to the number of health and medical journals in Africa.

African health and medical journals have been impressive in terms of productivity and citation impact within the period under review. Up to 29 of the journals met the average citation counts (333.3) to be ranked among the most frequently cited journals. Within the review period, three of the journals produced over 1000 papers each, with six of them receiving over 2000 


\section{ACCEPTED MANUSCRIPT}

citations each. This citation impact is an indication that many of the journals can compete favorably with other high profile health and medical journals in the world. Though Nigeria contributes more to the list of top journals, it is interesting to observe the geographical spread of the highly cited journals among the regions of Africa; namely West Africa (Nigeria and Ghana); East Africa (Kenya, Tanzania, and Uganda); Southern Africa (South Africa) and North Africa (Egypt, Libya, and Ethiopia). The distribution of highly productive and cited journals, as measured by Google Scholar, reflects earlier bibliometric studies in Africa as documented in studies by Onyancha (2008a \& 2008b), Ezema (2010b), and Mouton (2010). It is a source of concern that some highly productive journals receive very low citations. For instance, the Pan African Medical Journal, which produced the highest number of papers, received only 2957 citations with 1.07 cites per paper, while the South African Family Practice with 1748 papers has only 0.63 cites per paper. Could this be as a result of the quality of papers published in the journals or lack of access to such journals by researchers? The high uncited rates of these journals could be a result of very few researchers in the research scope of the journal or lack of access to the journals because of high subscription fees. Poor editorial quality could equally result in a lack of citations of journals articles. Since, all the journals in AJOL publish online full-text articles, the low citation rate of some of the journals could also be attributed to lack of popularity of AJOL among scholars outside Africa.

A search of the African health and medical journals in Thomson Reuters reveals a very disturbing result. Out of the 134 journals in the list, only 14 are tracked through the Journal Citation Report of WoS. Out of the 14 journals, four did not make the list of highly productive and cited journals. This calls into question the position of African scholarship in the global 


\section{ACCEPTED MANUSCRIPT}

scientific community. This skewed evaluation of journals in favor of Europe and America by Thomson Reuters has generated a lot of concern from various scholars (see Walter, Blosh, Hunt \& Fisher, 2003; Nwagwu, 2006; Loonen, Hage \& Kon, 2007; Ezema, 2010a; Nwagwu \& Onyancha, 2015). Obviously, the situation does not provide a level playing field for the global research community and, apparently, Scopus and especially Web of Science appear to exclude a large proportion of the global scientific community, and they may not remain globally competitive if this continues.

Apart from the fact that the performances of some of the journals are below expectation, it is also of concern that Scopus and WoS index very few African medical journals, ignoring so many of them with high citations and paper productivity. This leads one to ask: what are the criteria for selection of journals indexed in these databases - productivity or citations? Is it possible that with the performance of African health and medical journals, only $38.8 \%$ from Scopus and $10.5 \%$ from WoS meet the criteria? Though Scopus indexes only 52 of the journals, the database is evidently more inclusive than WoS.

\section{Issues in Medical Scholarly Communication in Africa}

These findings raise some issues in medical research and its communication in Africa and the entire international scientific community. With about 59 independent countries in Africa, the region has the potential capacity to generate high profile research output that will mitigate a number of medical and health challenges facing the continent, especially in the areas of tropical diseases and HIV/AIDS. However, it is surprising that only 20 out of the 59 countries have 


\section{ACCEPTED MANUSCRIPT}

medical and health journals in the AJOL. Findings indicate that Africa has 479 medical and health journals in Ulrich Global Periodical Directory. This implies that the continent is involved in medical and health research, which is published in journals. It is however surprising that only 30 percent of the journals are hosted in the AJOL database. Since AJOL was founded to provide wider visibility to African research productivity, which hitherto lacks international readership, African journal publishers as a matter of priority should register all their journals in the database to enhance wider visibility and readership.

Communication of research reports is usually sustained by reputable journals with a high profile editorial board, quality peer review mechanism, and regular publication. More than 140 journal titles in health and medical research in Africa are large enough to sustain medical research in the region. However, a close observation of these journals in relation to publication outputs and citation counts indicate that many of the journals performed below expectation (see Appendix 1 for details). This questions their continuous existence for the few that produced less than 50 papers in a five-year period. This should be of serious concern to the editorial board and the publishers of such journals.

Another issue of great concern is the sustainability of the journals through adequate funding or sponsorship. This is an area various governments and their agencies and professional bodies in the health sectors would need to address. From observations, many of the journals in Africa are self-sustaining through publication fees from authors. This usually erodes the quality of research published in the journals since editors must accept them to ensure sustenance. Failure to address this may result in inclusion of some of the journals in the list of predatory journals. 


\section{ACCEPTED MANUSCRIPT}

For libraries and librarians, the findings have provided a guide for journal subscriptions in their medical libraries. It also gives researchers in the field directions on the journals that would be a useful channel to follow in order to communicate their research papers to a wider audience. The debate about the use of journals indexed in Web of Science for evaluation and promotion of academic staff in some African universities is another issue of concern. Evidently, highly productive journals are excluded from WoS. This calls into question the criteria that WoS uses in the selection of journals indexed in the database. Would African researchers continue to depend on Euro-American biased database for promotion and retention of tenureship? This is where Nwagwu and Onyancha's (2015) call for democratisation of global scientific publications and their communication - an open access scholarly communication model that is not in tandem with the current journal platform requires serious support from African researchers to avoid academic imperialism from the West. 


\section{ACCEPTED MANUSCRIPT}

\section{References}

Bako, S. (2005). University research and development in Nigeria: time for paradigmatic shift. Paper prepared for $11^{\text {th }}$ General Assembly of CODESRIA, on Rethinking African Development: Beyond Impasse: Towards Alternatives, Maputo, Mozambique, $6^{\text {th }}-8^{\text {th }}$ December.

Beall, J. (2015). Criteria for determining predatory open access publishers. $3^{\text {rd }}$ ed. Retrieved from https://www.ufv.ca/.../Criteria-for-Determining-Predatory-Publishers.pdf

Beall, J. (2016). Beall's List of Predatory Publishers 2016. Retrieved from https://scholarlyoa.com/2016/01/05/bealls-list-of-predatory-publishers-2016/

Belter, C.W. (2015). Citation analysis as literature search method for systematic reviews. Journal of the Association of Information Science and Technology. doi: 10.1002/asi.23605.

Bradford, S.C. (1934). Sources of information on specific subjects. Engineering, 137, 85 - 86.

Christopher, M.M. \& Young K.M. (2015). Awareness of "predatory" open-access journals among prospective veterinary and medical authors attending scientific writing workshops. Frontiers in Veterinary Science, 2, 1 - 11. doi: 10.3389/fvets.2015.00022.

Diodato, V. (1994). Dictionary of bibliometrics. New York: Haworth.

Ezeh, A.C., Izugbara, C.O., Kabiru, C.W., Fonn, S., Kahn, K., Manderson, L., Undieh, A.S., Omigbodum, A. \& Thorogood, M. (2010). Building capacity for public and population health research in Africa: the consortium for advanced research training in Africa (CARTA) model. Global Health Action, 3. doi: 10.3402/gha.v3i0.5693. 


\section{ACCEPTED MANUSCRIPT}

Ezema, I.J. (2010a). Journal impact factors and the crisis of scholarly communication in Africa: the dilemma of Nigerian academics. Library Review, 59(5), 350 - 359. Retrieved from http://www.emeraldinsight.com/0024-2535.htm

Ezema, I.J. (2010b). Trends in Electronic Journal Publishing In Africa: An Analysis of African Journal Online (AJOL). Webology, 7(1), Retrieved from http://www.webology.org/2010/v7n1/a74.html

Ezema, I. J. \& Asogwa, B.E. (2012). Analysis of cited information sources in Nigerian agricultural research with emphasis on animal health and production. International Journal of Library and Information Science, 4(1), 1 - 9. Retrieved from http://www.academicjournals.org/ijlis

Ezema, I.J. \& Asogwa, B.E. (2014). Citation Analysis and Authorship Patterns of Two Linguistics Journals. Portal: Library and the Academy, 14(1), 67 - 85. Retrieved from http://muse.jhu.edu/login?auth=0\&type=summary\&url=/journals/portal_libraries_and_the_ academy/v014/14.1.ezema.html

Falagas, M.E., Karavasiou, A.I. \& Bliziotis, I.A. (2006). A bibliometric analysis of global trends of research productivity in tropical medicine. Acta Tropica, 99, $155-159$.

Falagas, M.E., Michalopoulos, A.S., Bliziotis, I.A. \& Soteriades, E.S. (2006). A bibliometric analysis by geographic area of published research in several biomedical fields, $1995-$ 2003. Canadian Medical Association Journal, 175(11), 1389 - 1391.

Fonn, S. (2005). African Ph.D research capacity in public health raison d'etre and how to build it. Global Forum Health Research, 3, $80-83$. 


\section{ACCEPTED MANUSCRIPT}

Gaillard, J. (2010). The characteristics of R\&D in developing countries. Science Technology \& Society, 15, $77-111$.

Glover S.W. \& Bowen, S.L. (2004). Bibliometric analysis of research published in tropical medicine and international health, 1996 - 2003. Tropical Medicine International Health, 9 , $1327-1330$.

Griggs, R.A. \& Christopher, A.N. (2016). Who's who in introductory physics textbooks: a citation analysis redux. Teaching of Psychology, 43(2), 108 - 119. doi:

$10.1177 / 0098628316636276$

Gu, W., Yuan, Y., Yang, H., Qi, G., Jin, X. \& Yan, J. (2015). A bibliometric analysis of the 100 most influential papers on COPD. International Journal of COPD, 10, 667-676.

Retrieved from http//:dx.doi.org/10.2147/COPD.574911

Harzing, A.W. (2007) Publish or Perish. Retrieved from http://www.harzing.com/pop.htm

Hendrix, D. (2008). An analysis of bibliometric indicators, National Institutes of Health funding, and faculty size at Association of American Medical Colleges medical schools, 1997 2007. Journal of Medical Library Association, 96 (4), 324 - 334.

Hertzel, D.H. (2003). Bibliometric history. In M.A Drake (ed.) Encyclopedia of Library and Information Science, vol. 2. New York: Marcel Dekker inc. 288 - 327.

Hirsch, J.E. (2005). An index to quantify an individual's scientific research output. PNAS, 102(46), 16569 - 16572. Retrieved from http://www.pnas.org/content/102/46/16569.full.pdf 


\section{ACCEPTED MANUSCRIPT}

Hsu, Y.H. \& Ho, Y.S. (2014). Highly cited articles in health care sciences and services field in Science Citation Index Expanded: A bibliometric analysis for 1958 - 2012. Methods of Information in Medicine, 6, $446-458$.

Ioannidis, J.P., Boyack, K.W. \& Klavans, R. (2014). Estimates of the continuously publishing core in the scientific workforce. PloS One, 9(7), e101698.

Kentucky Virtual Library. (2004a). How to do research: Why evaluate information sources?

Retrieved from http://www.kyvl.org/html/tutorial/research/whyeval.shtml

Kentucky Virtual Library. (2004b). How to do research: some useful tours. Retrieved from http://server2003.irandoc.ac.ir/InfoLit\%20Documents/web\%20site/Site_files/51.htm

Khan, A, Choudhury, N., Uddin, S., Hossain, L. \& Baur, L.A. (2016). Longitudinal trends in global obesity research and collaboration: a review using bibliometric metadata. Obesity Reviews. doi: 10.1111.obr.12372

Kim, J.N., Park, S.C., Yoo, S.W. \& Shen, H. (2010). Mapping health communication scholarship: breath, depth, and agenda of published research in health communication. Health Communication, 25, 6 - 7. Retrieved from http://dx.doi.org/10.1080/10410236.2010.507160

Lee, J.W. (2003). Science and health of the poor. Bulletin of World Health Organization, 81, 473.

Loonen, M.P.J, Hage, J.J \& Kon, M. (2007). Value of citation numbers and impact factor for analysis of plastic surgery research. Plastic Reconstruction Surgery, 120(7), 2082 - 2091. 


\section{ACCEPTED MANUSCRIPT}

Lor, P.J. (2007). Bridging the North-South divide in scholarly communication in Africa - a library and information science perspective. IFLA Journal, 33(4), 303 - 312. Retrieved from http://www.ifla.org

MacRoberts, M.H. \& MacRoberts, B.R. (1989). Problems of citation analysis: a critical review. Journal of American Society for Information Science, 40(5), 342 - 348.

Meho, L.I. (2007). The rise and rise of citation analysis. Physics World. Retrieved from http://www.physicsworld.org

Meho, L.I. \& Sonnenwald, D.H. (2000). Citation ranking versus peer evaluation of senior faculty research performance: a case study of Kurdish scholarship. Journal of America Society for Information Science, 51(2), 123 - 138. Retrieved from http://dlist.sir.arizona.edu/1318/01

Moed, H.F. (2005). Citation analysis in research evaluation. Berlin: Springer.

Mouton, J. (2010). International Social Science Council 2010 World Social Science Report Knowledge Divides: the state of social science in sub-Saharan Africa. Retrieved from http://unesdoc.unesco.org/images/0019/001906/190659E.pdf

Ngulube, P. (2010). Mapping mixed methods research in library and information science journals in sub-Saharan Africa 2004 - 2008. The International Information \& Library Review, 42 (4), 252 - 261. doi:10.1016/j.iilr.2010.10.005

Nwagwu, W.E. (2005). The landscape of biomedical research in Nigeria since 1967-2002. Learned Publishing, 18(3), 1- 15.

Nwagwu, W.E. (2006). Bibliometric analysis of quantity and quality of Nigeria's biomedical literature. LIBRES Library and Information Science Research Electronic Journal, 16(2). 


\section{ACCEPTED MANUSCRIPT}

Nwagwu, W.E. (2006, September 6-8). Organising and monitoring research production and performance in Africa: Towards Africa Citation Index. Paper presented at the International Conference on Bridging the Digital Divide in Scholarly Communication in the South: Threats and Opportunities. The Netherlands.

Nwagwu, W.E. \& Ojemeni, O. (2015). Penetration of Nigerian predatory biomedical open access journals 2007-2012: a bibliometric study. Learned Publishing, 28(1), 23 - 34. doi:10.1087/20150105

Nwagwu W.E. \& Onyancha, O.B. (2015). Back to the beginning - The journal is dead, long live science. The Journal of Academic Librarianship, 41 (5), 669-679. doi:10.1016/j.acalib.2015.06.005

Olukoju, A. (2004). The crisis of research and academic publishing in Nigerian Universities. P.T. Zeleza and A. Olukoshi (eds.). African Universities in the Twenty-first Century, vol. 2, Dakar: CODESRIA, $363-375$.

Onyancha, O.B. (2008a). Authorship patterns of the literature on HIV/AIDS in Eastern and Southern Africa: an exposition of the responsible authors, institutions and countries, 1980 2005. South African Journal of Library and Information Science, 74(1), 9-22.

Onyancha, O.B. (2008b). Growth, productivity, and scientific impact of sources of HIV/AIDS research information, with focus on Eastern and Southern Africa. African Journal of AIDS Research, 7(1), $55-70$.

Onyancha, O.B. \& Ocholla, D.N. (2007). Country-wise collaborations in HIV/AIDS research in Kenya and South Africa, 1980 - 2005. Libri, 57, 239 - 254. 


\section{ACCEPTED MANUSCRIPT}

Onyeka, I.N. (2014). Health research in Africa: Are we communicating our findings to the relevant stakeholders? African Health Science, 14(3), 779 - 781.

Pang, T., Sadana, R., Hanney, S., Bhutta, Z.A., Hyder, A.A. and Simon, J. (2003). Knowledge for better health - a conceptual framework and foundation for health research systems. Bulletin of World Health Organization, 8(11), 815 - 820.

Rosas, S.R. et al. (2011). Evaluating research and impact: a bibliometric analysis of research by NIH/NIAID HIV/AIDS clinical trials networks. PLos One, 6(3): e17428. doi:101371/journal.pone.0017428

Rosmarakis, E.E. et al. (2005). Estimates of global production in cardiovascular diseases research. International Journal of Cardiology, 100, 443 - 449.

Schoonbbaert, D. (2004). Citation pattern in tropical medicine journals. Tropical Medicine International Health, 9, $1142-1150$.

Seglen, P.O. (1997). Why the impact factor of journals should not be used for evaluating research. The BMJ, 314(7079), 498 - 502.

Shen, C \& Bjork, B.C. (2015). "Predatory" open access: a longitudinal study of article volumes and market characteristics. BMC Medicine, 13, 230. doi: 10.1186/s12916-015-0469-2

Simkhada, P.P., Baral, Y.R. \& Teijlingen, E.R. (2010). Health and Medical research in Nepal: a bibliometric review. Asia-Pacific Journal of Public Health, 22(4), 492 - 500.

Smith, D.R. (2008). Citation indexing and the development of academic journals in tropical medicine. Mem Inst Oswaldo Cruz, Rio de Janeiro, 103(3), 310 - 312. 


\section{ACCEPTED MANUSCRIPT}

Smith, D.R. (2010). Identifying a set of "core" journals in occupational health, part 2: lists derived from bibliometric techniques. Archives of Environmental \& Occupational Health, 65(3), $173-175$.

Stegehuis, C, Litvak, N. \& Waltman, L. (2015). Predicting the long-term citation impact of recent publications. Retrieved from arxiv.org/pdf/1503.09156.pdf

Tsai, Y.L, Lee, C.C., Chen, S.C. \& Yen, Z.S. (2006). Top-cited articles in emergency medicine. The American Journal of Emergency Medicine, 24, 647 - 654.

Walter, G., Blosh, S, Hunt, G \& Fisher, K. (2003). Counting on citations: A flawed way to measure quality. Medical Journal of Australia, 178(6), 280 - 281.

The World Bank. (2015). World Development Indicators 2015. Washing DC: International Bank for Reconstruction and Development. Retrieved from http://data.worldbank.org/sites/default/files/wdi-2015-frontmatter.pdf

World Health Organisation. (2014). Trends in maternal mortality: 1990 to 2013. Estimates by WHO, UNICEF, UNFPA, the World Bank and the United Nations Population Division. Geneva: WHO Press. Retrieved from http://apps.who.int/iris/bitstream/10665/112682/2/9789241507226_eng.pdf

World Health Organisation. (2015). World health statistics 2015. Geneva: WHO Press. Retrieved from http://apps.who.int/iris/bitstream/10665/170250/1/9789240694439_eng.pdf । 


\section{ACCEPTED MANUSCRIPT}

\section{Appendix 1. Rank list and details of all the African health and medical journals used for}

the study.

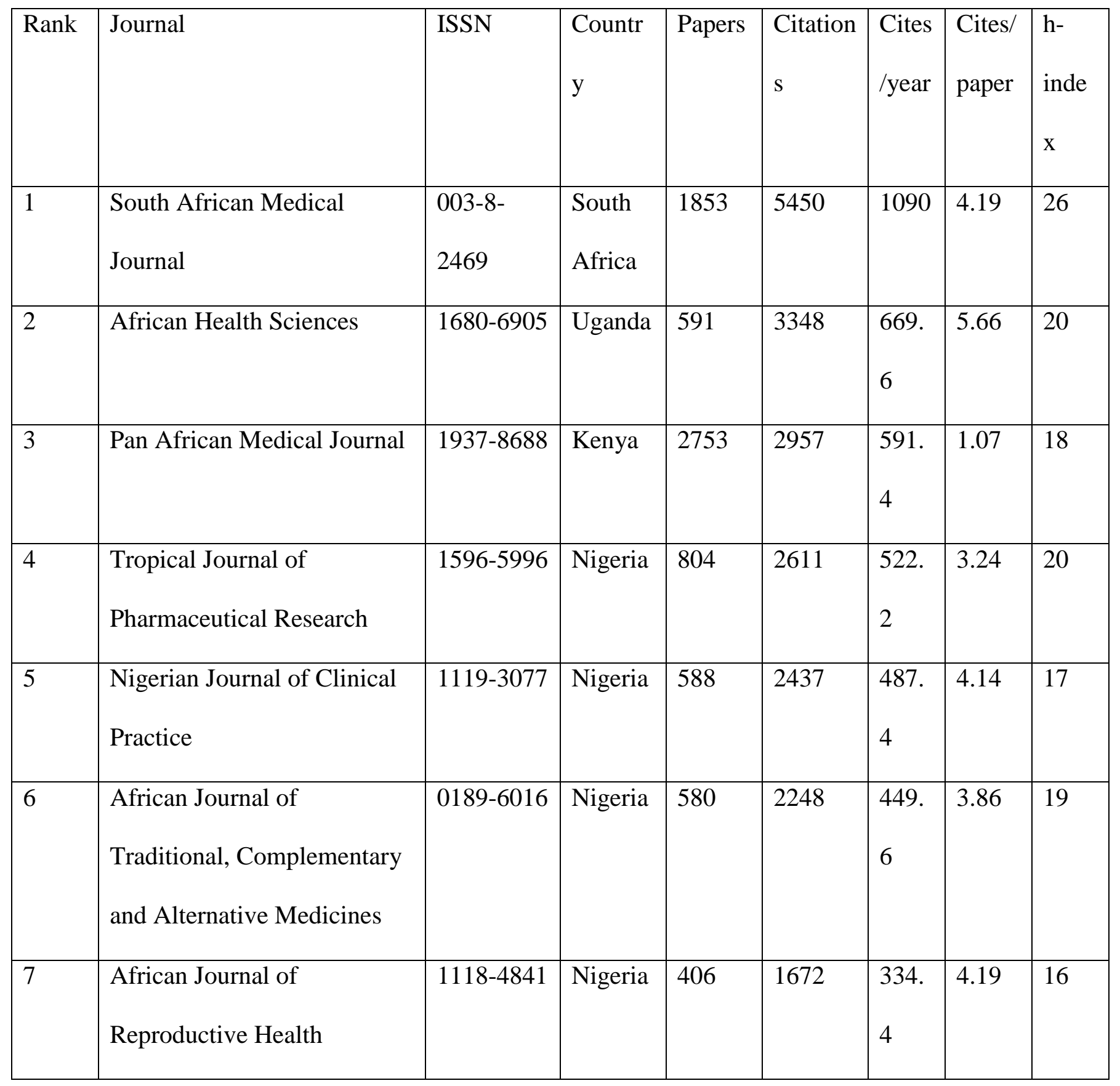




\section{ACCEPTED MANUSCRIPT}

\begin{tabular}{|c|c|c|c|c|c|c|c|c|}
\hline 8 & $\begin{array}{l}\text { Journal of Medicine and } \\
\text { Medical Sciences }\end{array}$ & $\begin{array}{l}1119- \\
3999\end{array}$ & Nigeria & 867 & 1565 & $\begin{array}{l}313 . \\
0\end{array}$ & 1.81 & 12 \\
\hline 9 & Annals of African Medicine & 1596-3519 & Nigeria & 290 & 1244 & $\begin{array}{l}248 . \\
8\end{array}$ & 4.29 & 15 \\
\hline 10 & $\begin{array}{l}\text { South African Family } \\
\text { Practice }\end{array}$ & $1726-426 x$ & $\begin{array}{l}\text { South } \\
\text { Africa }\end{array}$ & 1748 & 1109 & $\begin{array}{l}229 . \\
6\end{array}$ & 0.63 & 8 \\
\hline 11 & $\begin{array}{l}\text { African Journal of Paediatric } \\
\text { Surgery }\end{array}$ & $0189-6725$ & Nigeria & 418 & 1095 & $\begin{array}{l}219 . \\
0\end{array}$ & 2.62 & 12 \\
\hline 12 & Ghana Medical Journal & $0855-0328$ & Ghana & 205 & 992 & $\begin{array}{l}198 . \\
4\end{array}$ & 4.84 & 15 \\
\hline 13 & $\begin{array}{l}\text { Ethiopian Journal of Health } \\
\text { Sciences }\end{array}$ & $1029-1857$ & $\begin{array}{l}\text { Ethiopi } \\
\text { a }\end{array}$ & 211 & 948 & $\begin{array}{l}189 . \\
6\end{array}$ & 4.49 & 15 \\
\hline 14 & Nigerian Medical Journal & N/A & Nigeria & 363 & 943 & $\begin{array}{l}188 . \\
6\end{array}$ & 2.60 & 10 \\
\hline 15 & Nigerian Journal of Medicine & $1115-2613$ & Nigeria & 438 & 892 & $\begin{array}{l}178 . \\
4\end{array}$ & 2.04 & 10 \\
\hline 16 & $\begin{array}{l}\text { African Journal of AIDS } \\
\text { Research }\end{array}$ & $1608-5906$ & $\begin{array}{l}\text { South } \\
\text { Africa }\end{array}$ & 207 & 814 & $\begin{array}{l}162 . \\
8\end{array}$ & 3.93 & 13 \\
\hline 17 & $\begin{array}{l}\text { Annals of Medical and } \\
\text { Health Sciences Research }\end{array}$ & $2141-9248$ & Nigeria & 244 & 807 & $\begin{array}{l}161 . \\
4\end{array}$ & 3.31 & 12 \\
\hline 18 & Libyan Journal of Medicine & $1819-6357$ & Libya & 182 & 738 & 147. & 4.05 & 12 \\
\hline
\end{tabular}




\section{ACCEPTED MANUSCRIPT}

\begin{tabular}{|c|c|c|c|c|c|c|c|c|}
\hline & & & & & & 6 & & \\
\hline 19 & $\begin{array}{l}\text { Ethiopian Journal of Health } \\
\text { Development }\end{array}$ & $1021-6790$ & $\begin{array}{l}\text { Ethiopi } \\
\text { a }\end{array}$ & 188 & 660 & $\begin{array}{l}132 . \\
0\end{array}$ & 3.51 & 13 \\
\hline 20 & $\begin{array}{l}\text { West African Journal of } \\
\text { Medicine }\end{array}$ & $\begin{array}{l}0189- \\
160 X\end{array}$ & Nigeria & 288 & 648 & $\begin{array}{l}129 . \\
6\end{array}$ & 2.25 & 11 \\
\hline 21 & $\begin{array}{l}\text { Tanzania Journal of Health } \\
\text { Research }\end{array}$ & $\begin{array}{l}0856- \\
6496\end{array}$ & $\begin{array}{l}\text { Tanzani } \\
\text { a }\end{array}$ & 224 & 642 & $\begin{array}{l}128 . \\
4\end{array}$ & 2.87 & 11 \\
\hline 22 & $\begin{array}{l}\text { South African Journal of } \\
\text { Clinical Nutrition }\end{array}$ & $\begin{array}{l}003-8- \\
2469\end{array}$ & $\begin{array}{l}\text { South } \\
\text { Africa }\end{array}$ & 200 & 537 & $\begin{array}{l}107 . \\
4\end{array}$ & 2.69 & 12 \\
\hline 23 & $\begin{array}{l}\text { Southern African Journal of } \\
\text { HIV Medicine }\end{array}$ & 0038-2469 & $\begin{array}{l}\text { South } \\
\text { Africa }\end{array}$ & 180 & 524 & $\begin{array}{l}104 . \\
8\end{array}$ & 2.91 & 10 \\
\hline 24 & $\begin{array}{l}\text { South African Journal of } \\
\text { Surgery }\end{array}$ & $0038-2361$ & $\begin{array}{l}\text { South } \\
\text { Africa }\end{array}$ & 241 & 495 & 99.0 & 2.05 & 10 \\
\hline 25 & $\begin{array}{l}\text { Egyptian Journal of Medical } \\
\text { Human Genetics }\end{array}$ & $1110-8630$ & Egypt & 224 & 457 & 91.4 & 2.04 & 9 \\
\hline 26 & Malawi Medical Journal & N/A & Malawi & 287 & 444 & 88.8 & 1.55 & 10 \\
\hline 27 & $\begin{array}{l}\text { East African Journal of } \\
\text { Public Health }\end{array}$ & 0856-8960 & $\begin{array}{l}\text { Tanzani } \\
\text { a }\end{array}$ & 278 & 427 & 85.4 & 1.54 & 8 \\
\hline 28 & $\begin{array}{l}\text { Alexandria Journal of } \\
\text { Medicine }\end{array}$ & $2090-2948$ & Egypt & 262 & 373 & 74.6 & 1.42 & 8 \\
\hline 29 & African Journal of & \begin{tabular}{|l}
$1119-5096$ \\
\end{tabular} & Nigeria & 251 & 371 & 71.2 & 1.48 & 9 \\
\hline
\end{tabular}




\section{ACCEPTED MANUSCRIPT}

\begin{tabular}{|c|c|c|c|c|c|c|c|c|}
\hline & Biomedical Research & & & & & & & \\
\hline 30 & Health SA Gesondheid & $1025-9848$ & $\begin{array}{l}\text { South } \\
\text { Africa }\end{array}$ & 153 & 314 & 62.8 & 2.05 & 8 \\
\hline 31 & $\begin{array}{l}\text { Arab Journal of Nephrology } \\
\text { and Transplantation }\end{array}$ & $\begin{array}{l}1858- \\
554 \mathrm{X}\end{array}$ & Sudan & 102 & 303 & 60.6 & 2.97 & 9 \\
\hline 32 & $\begin{array}{l}\text { Journal of Surgical } \\
\text { Technique and Case Report }\end{array}$ & $2006-8808$ & Nigeria & 144 & 284 & 56.8 & 1.97 & 7 \\
\hline 33 & $\begin{array}{l}\text { South African Journal of } \\
\text { Psychiatry }\end{array}$ & $\begin{array}{l}003-8- \\
2469\end{array}$ & $\begin{array}{l}\text { South } \\
\text { Africa }\end{array}$ & 420 & 268 & 53.6 & 0.64 & 7 \\
\hline 34 & $\begin{array}{l}\text { South African Journal of } \\
\text { Child Health }\end{array}$ & N/A & $\begin{array}{l}\text { South } \\
\text { Africa }\end{array}$ & 197 & 267 & 53.4 & 1.36 & 7 \\
\hline 35 & $\begin{array}{l}\text { Southern African Journal of } \\
\text { Anaesthesia and Analgesia }\end{array}$ & $1027-9148$ & $\begin{array}{l}\text { South } \\
\text { Africa }\end{array}$ & 407 & 265 & 53.0 & 0.65 & 5 \\
\hline 36 & $\begin{array}{l}\text { African Journal of Clinical } \\
\text { and Experimental } \\
\text { Microbiology }\end{array}$ & $\begin{array}{l}1595- \\
689 X\end{array}$ & Nigeria & 143 & 262 & 52.4 & 1.83 & 8 \\
\hline 37 & East African Medical Journal & $0012835 x$ & Kenya & 384 & 257 & 51.4 & 0.67 & 7 \\
\hline 38 & Scientific Medical Journal & $1110-5607$ & Egypt & 479 & 243 & 48.6 & 0.66 & 6 \\
\hline 39 & $\begin{array}{l}\text { Continuing Medical } \\
\text { Education }\end{array}$ & N/A & $\begin{array}{l}\text { South } \\
\text { Africa }\end{array}$ & 743 & 237 & 47.4 & 0.32 & 6 \\
\hline 40 & Journal of Medicine and & \begin{tabular}{|l|}
$1596-6941$ \\
\end{tabular} & Nigeria & 186 & 237 & 47.4 & 1.27 & 7 \\
\hline
\end{tabular}




\section{ACCEPTED MANUSCRIPT}

\begin{tabular}{|c|c|c|c|c|c|c|c|c|}
\hline & Biomedical Research & & & & & & & \\
\hline 41 & $\begin{array}{l}\text { South African Journal of } \\
\text { Sports Medicine }\end{array}$ & $1015-5163$ & $\begin{array}{l}\text { South } \\
\text { Africa }\end{array}$ & 149 & 220 & 44.0 & 1.48 & 8 \\
\hline 42 & $\begin{array}{l}\text { Nigerian Journal of } \\
\text { Paediatrics }\end{array}$ & $0302-4660$ & Nigeria & 241 & 213 & 42.6 & 0.88 & 5 \\
\hline 43 & $\begin{array}{l}\text { International Journal of } \\
\text { Medicine and Biomedical } \\
\text { Research }\end{array}$ & $2315-5019$ & Nigeria & 90 & 198 & 66.0 & 2.2 & 9 \\
\hline 44 & $\begin{array}{l}\text { Internet Journal of Medical } \\
\text { Update-EJOURNAL }\end{array}$ & $1694-0423$ & $\begin{array}{l}\text { Mauriti } \\
\text { us }\end{array}$ & 109 & 193 & 38.6 & 1.77 & 5 \\
\hline 45 & $\begin{array}{l}\text { East and Central African } \\
\text { Journal of Surgery }\end{array}$ & $2073-9990$ & Uganda & 263 & 158 & 31.6 & 0.60 & 5 \\
\hline 46 & Annals of Nigerian Medicine & $0331-3131$ & Nigeria & 101 & 151 & 30.2 & 1.5 & 6 \\
\hline 47 & $\begin{array}{l}\text { International Journal of } \\
\text { Health Research }\end{array}$ & $1596-9819$ & Nigeria & 69 & 138 & 27.6 & 2.36 & 5 \\
\hline 48 & $\begin{array}{l}\text { Nigerian Quarterly Journal } \\
\text { of Hospital Medicine }\end{array}$ & $\begin{array}{l}0189- \\
2657\end{array}$ & Nigeria & 114 & 128 & 26.5 & 1,12 & 6 \\
\hline 49 & $\begin{array}{l}\text { Journal of Medical and } \\
\text { Biomedical Sciences }\end{array}$ & $2026-6294$ & Ghana & 58 & 127 & 25.4 & 2.19 & 6 \\
\hline 50 & African Journal of Urology & $1110-5704$ & Egypt & 261 & 120 & 24.0 & 0.46 & 4 \\
\hline 51 & Nigerian Journal of Surgery & \begin{tabular}{|l|}
$1117-6806$ \\
\end{tabular} & Nigeria & 82 & 114 & 22.8 & 1.39 & 4 \\
\hline
\end{tabular}




\section{ACCEPTED MANUSCRIPT}

\begin{tabular}{|c|c|c|c|c|c|c|c|c|}
\hline 52 & $\begin{array}{l}\text { Sierra Leone Journal of } \\
\text { Biomedical Research }\end{array}$ & $2076-6270$ & $\begin{array}{l}\text { Sierra } \\
\text { Leone }\end{array}$ & 61 & 113 & 22.6 & 1.85 & 5 \\
\hline 53 & $\begin{array}{l}\text { Journal of Child and } \\
\text { Adolescent Mental Health }\end{array}$ & $1728-0583$ & $\begin{array}{l}\text { South } \\
\text { Africa }\end{array}$ & 125 & 112 & 22.4 & 0.9 & 6 \\
\hline 54 & $\begin{array}{l}\text { South African Journal of } \\
\text { Obstetrics and Gynaecology }\end{array}$ & $0038-2329$ & $\begin{array}{l}\text { South } \\
\text { Africa }\end{array}$ & 114 & 112 & 22.4 & 0.98 & 5 \\
\hline 55 & $\begin{array}{l}\text { Journal of Medicine in the } \\
\text { Tropics }\end{array}$ & $0795-9168$ & Nigeria & 147 & 110 & 22.0 & 0.75 & 5 \\
\hline 56 & $\begin{array}{l}\text { Annals of Ibadan } \\
\text { Postgraduate Medicine }\end{array}$ & \begin{tabular}{|l|}
$1597-1627$ \\
\end{tabular} & Nigeria & 79 & 98 & 19.6 & 1.24 & 5 \\
\hline 57 & $\begin{array}{l}\text { African Journal of Drug and } \\
\text { Alcohol Studies }\end{array}$ & $1531-4065$ & Nigeria & 58 & 96 & 19.2 & 1.66 & 6 \\
\hline 58 & Annals of Pediatric Surgery & $1687-4137$ & Egypt & 141 & 95 & 19.0 & 0.67 & 4 \\
\hline 59 & $\begin{array}{l}\text { African Journal of Infectious } \\
\text { Diseases }\end{array}$ & $2006-0165$ & Nigeria & 96 & 91 & 18.2 & 0.95 & 5 \\
\hline 60 & $\begin{array}{l}\text { Egyptian Journal of Pediatric } \\
\text { Allergy and Immunology } \\
\text { (The) }\end{array}$ & $2134-8934$ & Egypt & 111 & 85 & 17.0 & 0.77 & 6 \\
\hline 61 & Nigerian Health Journal & $1597-4292$ & Nigeria & 95 & 72 & 14.6 & 0.76 & 5 \\
\hline 62 & $\begin{array}{l}\text { Nigerian Journal of } \\
\text { Parasitology }\end{array}$ & $1117-4145$ & Nigeria & 157 & 70 & 14.0 & 0.45 & 4 \\
\hline
\end{tabular}




\section{ACCEPTED MANUSCRIPT}

\begin{tabular}{|c|c|c|c|c|c|c|c|c|}
\hline 63 & $\begin{array}{l}\text { Journal of Basic and Clinical } \\
\text { Reproductive Sciences }\end{array}$ & 2320-2041 & Nigeria & 77 & 69 & 13.8 & 0.90 & 4 \\
\hline 64 & Medical Journal of Zambia & $\begin{array}{l}0047- \\
651 X\end{array}$ & Zambia & 111 & 62 & 12.4 & 0.56 & 3 \\
\hline 65 & $\begin{array}{l}\text { Southern African Journal of } \\
\text { Critical Care }\end{array}$ & $1562-8264$ & $\begin{array}{l}\text { South } \\
\text { Africa }\end{array}$ & 47 & 60 & 12.0 & 1.28 & 4 \\
\hline 66 & $\begin{array}{l}\text { African Journal of Health } \\
\text { Sciences }\end{array}$ & $1022-9272$ & Kenya & 45 & 57 & 11.4 & 1.27 & 5 \\
\hline 67 & $\begin{array}{l}\text { Journal of Pharmaceutical } \\
\text { and Allied Sciences }\end{array}$ & \begin{tabular}{|l|}
$1596-8499$ \\
\end{tabular} & Nigeria & 145 & 56 & 11.2 & 0.39 & 3 \\
\hline 68 & $\begin{array}{l}\text { Clinics in Mother and Child } \\
\text { Health }\end{array}$ & $1812-5840$ & $\begin{array}{l}\text { Camero } \\
\text { un }\end{array}$ & 59 & 55 & 11.0 & 0.93 & 4 \\
\hline 69 & Afrimedic Journal & $\begin{array}{l}2141- \\
162 X\end{array}$ & Nigeria & 80 & 54 & 13.5 & 0.68 & 4 \\
\hline 70 & Sahel Medical Journal & $\begin{array}{l}1118- \\
8561\end{array}$ & Nigeria & 175 & 53 & 10.6 & 0.30 & 3 \\
\hline 71 & $\begin{array}{l}\text { Port Harcourt Medical } \\
\text { Journal }\end{array}$ & $0795-3038$ & Nigeria & 178 & 52 & 10.4 & 0.29 & 3 \\
\hline 72 & $\begin{array}{l}\text { Tropical Journal of } \\
\text { Obstetrics and Gynaecology }\end{array}$ & $\begin{array}{l}0189- \\
5178\end{array}$ & Nigeria & 179 & 49 & 9.8 & 0.27 & 3 \\
\hline 73 & Nigerian Medical & 01890964 & Nigeria & 132 & 43 & 8.6 & 0.33 & 3 \\
\hline
\end{tabular}




\section{ACCEPTED MANUSCRIPT}

\begin{tabular}{|c|c|c|c|c|c|c|c|c|}
\hline & Practitioner & & & & & & & \\
\hline 74 & $\begin{array}{l}\text { Sudan Journal of Medical } \\
\text { Sciences }\end{array}$ & $1858-5051$ & Sudan & 177 & 41 & 8.2 & 0.23 & 3 \\
\hline 75 & $\begin{array}{l}\text { East African Orthopaedic } \\
\text { Journal }\end{array}$ & 1994-1072 & Kenya & 64 & 41 & 8.2 & 0.64 & 3 \\
\hline 76 & $\begin{array}{l}\text { Obstetrics and Gynaecology } \\
\text { Forum }\end{array}$ & $1027-9148$ & $\begin{array}{l}\text { South } \\
\text { Africa }\end{array}$ & 156 & 39 & 7.8 & 0.25 & 3 \\
\hline 77 & $\begin{array}{l}\text { Benin Journal of } \\
\text { Postgraduate Medicine }\end{array}$ & 0795-0268 & Nigeria & 10 & 37 & 7.4 & 3.7 & 3 \\
\hline 78 & Jos Journal of Medicine & $2006-0734$ & Nigeria & 96 & 36 & 7.2 & 0.38 & 2 \\
\hline 79 & $\begin{array}{l}\text { East and Central African } \\
\text { Journal of Pharmaceutical } \\
\text { Sciences }\end{array}$ & $\begin{array}{l}1026- \\
552 X\end{array}$ & Kenya & 53 & 35 & 7.0 & 0.66 & 3 \\
\hline 80 & $\begin{array}{l}\text { African Journal of } \\
\text { Physiotherapy and } \\
\text { Rehabilitation Sciences }\end{array}$ & $2141-8322$ & Nigeria & 32 & 35 & 7.0 & 1.09 & 3 \\
\hline 81 & Annals of African Surgery & $1999-9674$ & Kenya & 130 & 34 & 6.8 & 0.26 & 3 \\
\hline 82 & Anatomy Journal of Africa & $2305-9478$ & Kenya & 39 & 32 & 6.4 & 0.82 & 3 \\
\hline 83 & $\begin{array}{l}\text { African Journal of } \\
\text { Neurological Sciences }\end{array}$ & $1992-2647$ & $\begin{array}{l}\text { Cote } \\
\text { d'Ivoire }\end{array}$ & 100 & 31 & 6.2 & 0.31 & 3 \\
\hline 84 & Nigerian Journal of & $1596-4582$ & Nigeria & 90 & 31 & 6.2 & 0.34 & 2 \\
\hline
\end{tabular}




\section{ACCEPTED MANUSCRIPT}

\begin{tabular}{|c|c|c|c|c|c|c|c|c|}
\hline & Orthopaedics and Trauma & & & & & & & \\
\hline 85 & $\begin{array}{l}\text { Journal of Community } \\
\text { Medicine and Primary } \\
\text { Health Care }\end{array}$ & $\begin{array}{l}0794- \\
7410\end{array}$ & Nigeria & 49 & 31 & 6.2 & 0.63 & 2 \\
\hline 86 & $\begin{array}{l}\text { Rwanda Journal of Health } \\
\text { Sciences }\end{array}$ & $\begin{array}{l}2226- \\
728 X\end{array}$ & $\begin{array}{l}\text { Rwand } \\
\text { a }\end{array}$ & 17 & 29 & 9.67 & 1.71 & 3 \\
\hline 87 & $\begin{array}{l}\text { Tropical Journal of Health } \\
\text { Sciences }\end{array}$ & $1117-4153$ & Nigeria & 87 & 26 & 5.2 & 0.30 & 2 \\
\hline 88 & $\begin{array}{l}\text { Central African Journal of } \\
\text { Medicine }\end{array}$ & $0008-9176$ & $\begin{array}{l}\text { Zimbab } \\
\text { we }\end{array}$ & 38 & 23 & 4.6 & 0.61 & 2 \\
\hline 89 & Nigerian Hospital Practice & $1597-7889$ & Nigeria & 88 & 22 & 4.4 & 0.26 & 2 \\
\hline 90 & $\begin{array}{l}\text { Nigerian Journal of Clinical } \\
\text { Medicine }\end{array}$ & $2141-1123$ & Nigeria & 47 & 22 & 4.4 & 0.47 & 3 \\
\hline 91 & $\begin{array}{l}\text { Nigerian Journal of } \\
\text { Pharmaceutical Research }\end{array}$ & 0189-8434 & Nigeria & 46 & 20 & 4.0 & 0.43 & 1 \\
\hline 92 & Nigerian Dental Journal & 0189-1006 & Nigeria & 62 & 18 & 3.6 & 0.2 & 2 \\
\hline 93 & Orient Journal of Medicine & $1115-0521$ & Nigeria & 83 & 17 & 3.4 & 0.2 & 2 \\
\hline 94 & $\begin{array}{l}\text { Nigerian Journal of } \\
\text { Ophthalmology }\end{array}$ & 0189-9171 & Nigeria & 63 & 16 & 3.2 & 0.25 & 2 \\
\hline 95 & $\begin{array}{l}\text { Tropical Journal of Medical } \\
\text { Research }\end{array}$ & 1119-0388 & Nigeria & 80 & 15 & 3.0 & 0.19 & 2 \\
\hline
\end{tabular}




\section{ACCEPTED MANUSCRIPT}

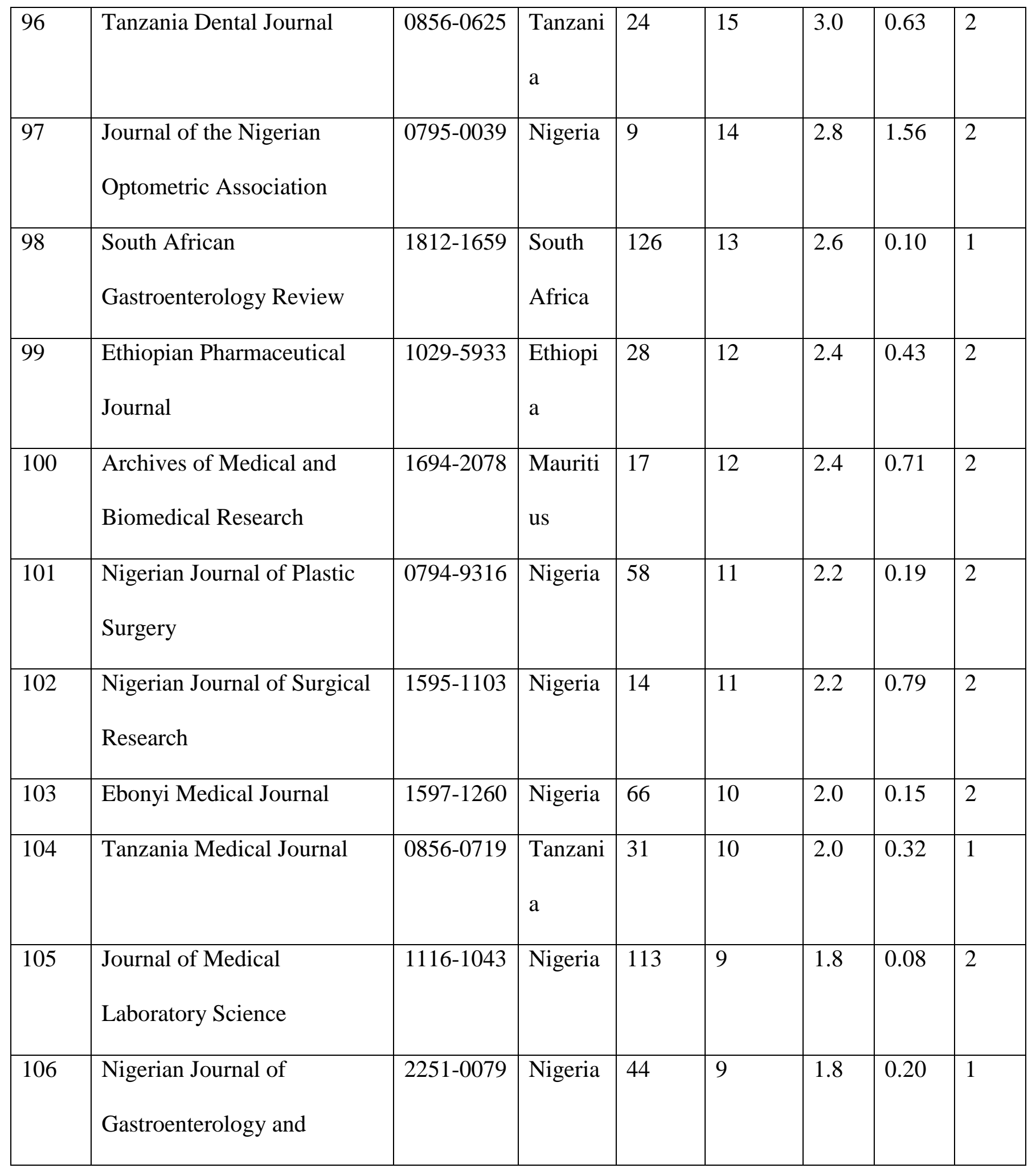




\section{ACCEPTED MANUSCRIPT}

\begin{tabular}{|c|c|c|c|c|c|c|c|c|}
\hline & Hepatology & & & & & & & \\
\hline 107 & $\begin{array}{l}\text { African Journal of } \\
\text { Anaesthesia and Intensive } \\
\text { Care }\end{array}$ & $0794-2184$ & Nigeria & 43 & 9 & 1.8 & 0.21 & 1 \\
\hline 108 & $\begin{array}{l}\text { Nigerian Journal of Natural } \\
\text { Products and Medicine }\end{array}$ & $1118-6267$ & Nigeria & 30 & 9 & 1.8 & 0.30 & 2 \\
\hline 109 & $\begin{array}{l}\text { West African Journal of } \\
\text { Pharmacology and Drug } \\
\text { Research }\end{array}$ & $\begin{array}{l}0303- \\
691 X\end{array}$ & Nigeria & 18 & 9 & 1.8 & 0.50 & 2 \\
\hline 110 & $\begin{array}{l}\text { West African Journal of } \\
\text { Radiology }\end{array}$ & \begin{tabular}{|l|}
$1115-3474$ \\
\end{tabular} & Nigeria & 73 & 8 & 1.6 & 0.11 & 1 \\
\hline 111 & $\begin{array}{l}\text { Journal of the Eritrean } \\
\text { Medical Association }\end{array}$ & 1998-6017 & Eritrea & 3 & 8 & 1.6 & 2.67 & 1 \\
\hline 112 & $\begin{array}{l}\text { Savannah Journal of Medical } \\
\text { Research and Practice }\end{array}$ & $2276-6839$ & Nigeria & 37 & 7 & 1.4 & 0.19 & 1 \\
\hline 113 & $\begin{array}{l}\text { Zagazig Journal of } \\
\text { Occupational Health and } \\
\text { Safety }\end{array}$ & $1687-8671$ & Egypt & 2 & 6 & 1.2 & 3.00 & 2 \\
\hline 114 & $\begin{array}{l}\text { Nigerian Journal of General } \\
\text { Practice }\end{array}$ & $1118-4647$ & Nigeria & 63 & 5 & 1.0 & 0.08 & 1 \\
\hline 115 & African Journal of & $2307-2482$ & Kenya & 35 & 5 & 1.0 & 0.14 & 1 \\
\hline
\end{tabular}




\section{ACCEPTED MANUSCRIPT}

\begin{tabular}{|c|c|c|c|c|c|c|c|c|}
\hline & Rheumatology & & & & & & & \\
\hline 116 & $\begin{array}{l}\text { Nigerian Journal of Health } \\
\text { and Biomedical Sciences }\end{array}$ & $1595-8272$ & Nigeria & 13 & 4 & 0.8 & 0.31 & 1 \\
\hline 117 & $\begin{array}{l}\text { Journal of Medical } \\
\text { Investigation and Practice }\end{array}$ & $9783-1230$ & Nigeria & 10 & 3 & 1.0 & 0.30 & 1 \\
\hline 118 & IMTU Medical Journal & $1821-7613$ & $\begin{array}{l}\text { Tanzani } \\
\text { a }\end{array}$ & 38 & 2 & 0.4 & 0.05 & 1 \\
\hline 119 & $\begin{array}{l}\text { South African Journal of } \\
\text { Radiology }\end{array}$ & $0038-2469$ & $\begin{array}{l}\text { South } \\
\text { Africa }\end{array}$ & 35 & 2 & 0.4 & 0.06 & 1 \\
\hline 120 & $\begin{array}{l}\text { Nigerian Journal of Surgical } \\
\text { Sciences }\end{array}$ & $1116-5898$ & Nigeria & 23 & 2 & 0.4 & 0.09 & 1 \\
\hline 121 & Nigerian Endocrine Practice & $2251-0362$ & Nigeria & 21 & 2 & 0.4 & 0.1 & 1 \\
\hline 122 & $\begin{array}{l}\text { International Journal of } \\
\text { Medicine and Health } \\
\text { Development }\end{array}$ & $188-2601$ & Nigeria & 9 & 2 & 0.4 & 0.22 & 1 \\
\hline 123 & $\begin{array}{l}\text { Sudanese Journal of } \\
\text { Dermatology }\end{array}$ & $1815-3941$ & Sudan & 9 & 2 & 0.4 & 0.22 & 1 \\
\hline 124 & Archives of Ibadan Medicine & $1467-6958$ & Nigeria & 1 & 2 & 0.4 & 2.0 & 1 \\
\hline 125 & $\begin{array}{l}\text { Journal of Experimental and } \\
\text { Clinical Anatomy }\end{array}$ & $1596-2393$ & Nigeria & 45 & 1 & 0.2 & 0.02 & 1 \\
\hline 126 & Highland Medical Research & $1596-2407$ & Nigeria & 38 & 1 & 0.2 & 0.03 & 1 \\
\hline
\end{tabular}




\section{ACCEPTED MANUSCRIPT}

\begin{tabular}{|c|c|c|c|c|c|c|c|c|}
\hline & Journal & & & & & & & \\
\hline 127 & $\begin{array}{l}\text { Journal of Health and Visual } \\
\text { Sciences }\end{array}$ & 1119-2006 & Nigeria & 34 & 1 & 0.2 & 0.03 & 1 \\
\hline 128 & $\begin{array}{l}\text { Nigerian Journal of Family } \\
\text { Practice }\end{array}$ & $2141-9884$ & Nigeria & 16 & 1 & 0.2 & 0.06 & 1 \\
\hline 129 & $\begin{array}{l}\text { Global Journal of Medical } \\
\text { Sciences }\end{array}$ & 1596-2911 & Nigeria & 14 & 1 & 0.20 & 0.07 & 1 \\
\hline 130 & $\begin{array}{l}\text { Revue de Médecine et de } \\
\text { Pharmacie }\end{array}$ & $2410-8936$ & $\begin{array}{l}\text { Camero } \\
\text { un }\end{array}$ & 58 & 0 & 0.0 & 0.0 & 0 \\
\hline 131 & $\begin{array}{l}\text { Nigerian Journal of } \\
\text { Postgraduate Medicine }\end{array}$ & 2006-8530 & Nigeria & 6 & 0 & 0.0 & 0.0 & 0 \\
\hline 132 & $\begin{array}{l}\text { Egyptian Journal of Medical } \\
\text { Laboratory Sciences }\end{array}$ & 1110-5593 & Egypt & 4 & 0 & 0.0 & 0.0 & 0 \\
\hline 133 & $\begin{array}{l}\text { International Journal of } \\
\text { Malaria and Tropical } \\
\text { Diseases (IJMTD) }\end{array}$ & 1596-3381 & Nigeria & 1 & 0 & 0.0 & 0.0 & 0 \\
\hline 134 & $\begin{array}{l}\text { Journal of Biomedical } \\
\text { Investigation }\end{array}$ & $1597-0043$ & Nigeria & 1 & 0 & 0.0 & 0.0 & 0.0 \\
\hline $135^{*}$ & $\begin{array}{l}\text { Journal of Endocrinology, } \\
\text { Metabolism and Diabetes of } \\
\text { South Africa }\end{array}$ & $\begin{array}{l}003-8- \\
2469\end{array}$ & $\begin{array}{l}\text { South } \\
\text { Africa }\end{array}$ & & & & & \\
\hline
\end{tabular}




\section{ACCEPTED MANUSCRIPT}

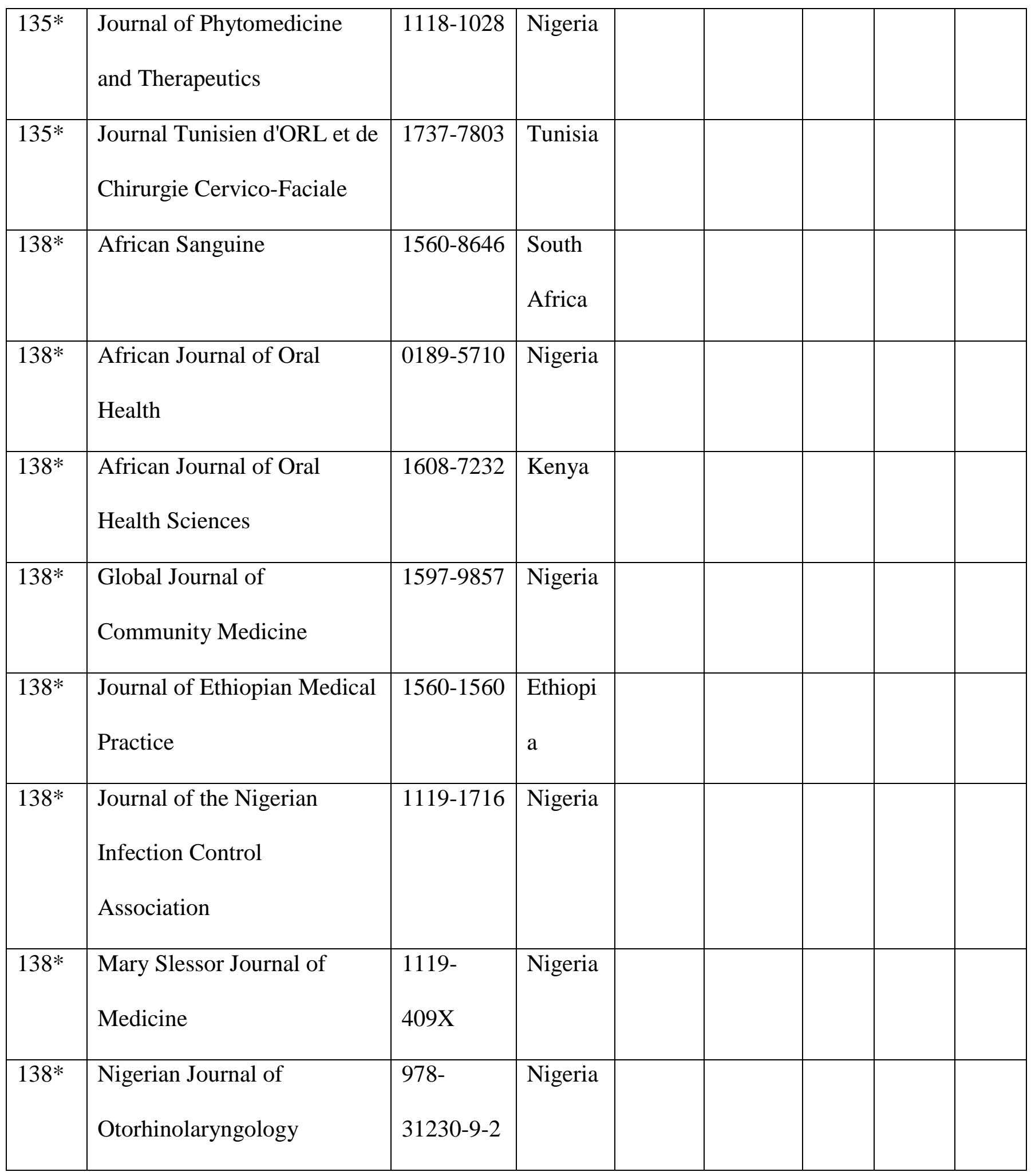




\section{ACCEPTED MANUSCRIPT}

\begin{tabular}{|l|l|l|l|l|l|l|l|l|}
\hline & Total & & & 25,495 & 44,658 & & & \\
\hline
\end{tabular}

Average paper productivity $=190.3$

Average Citation $=333.3$ Average

cite/paper $=1.8$

*Journals that were not recognised by the software 


\section{ACCEPTED MANUSCRIPT}

Table 1. Country-wise distribution of health and medical journals in Africa.

\begin{tabular}{|c|c|c|c|c|c|c|c|c|}
\hline $\mathrm{S} / \mathrm{N}$ & $\begin{array}{l}\text { Country of } \\
\text { Origin }\end{array}$ & $\begin{array}{l}\text { Total } \\
\text { journals } \\
\text { in } \\
\text { Ulrich's }\end{array}$ & $\begin{array}{l}\text { Medical } \\
\text { journals } \\
\text { in } \\
\text { Ulrich's }\end{array}$ & $\begin{array}{l}\% \text { of } \\
\text { Ulrich's } \\
\text { medical } \\
\text { journals }\end{array}$ & $\begin{array}{l}\text { Total } \\
\text { journals } \\
\text { in AJOL }\end{array}$ & $\begin{array}{l}\text { Medical } \\
\text { journals } \\
\text { in AJOL }\end{array}$ & $\begin{array}{l}\% \text { of } \\
\text { AJOL } \\
\text { medical } \\
\text { journals }\end{array}$ & $\begin{array}{l}\% \text { of } \\
\text { AJOL to } \\
\text { Ulrich's } \\
\text { medical } \\
\text { journals }\end{array}$ \\
\hline 1 & Nigeria & 713 & 186 & 26.1 & 218 & 79 & 36.2 & 42.5 \\
\hline 2 & $\begin{array}{l}\text { South } \\
\text { Africa }\end{array}$ & 575 & 105 & 18.3 & 94 & 20 & 21.3 & \begin{tabular}{|l|l}
19.0 \\
\end{tabular} \\
\hline 3 & Kenya & 112 & 25 & 22.3 & 29 & 9 & 31.0 & 36.0 \\
\hline 4 & Egypt & 275 & 104 & 37.8 & 14 & 8 & 57.1 & 7.7 \\
\hline 5 & Tanzania & 41 & 5 & 12.2 & 18 & 5 & 27.8 & 100 \\
\hline 6 & \begin{tabular}{|l|} 
Ethiopia \\
\end{tabular} & 57 & 12 & 21.1 & 29 & 4 & 13.8 & 33.3 \\
\hline 7 & Sudan & 13 & 8 & 61.5 & 3 & 3 & 100 & 37.5 \\
\hline 8 & Cameroun & 12 & 2 & 16.7 & 8 & 2 & 25.0 & 100 \\
\hline 9 & Ghana & 48 & 4 & 8.3 & 27 & 2 & 7.4 & 50.0 \\
\hline 10 & Mauritius & 5 & 1 & 20.0 & 3 & 2 & 66.7 & 200 \\
\hline 11 & Uganda & 18 & 6 & 33.3 & 12 & 2 & 16.7 & 33.3 \\
\hline 12 & Eritrea & 1 & 0 & 0.0 & 1 & 1 & 100 & 0.0 \\
\hline 13 & $\begin{array}{l}\text { Cote } \\
\text { d'Ivoire }\end{array}$ & 9 & 1 & 11.1 & 4 & 1 & 25.0 & 100 \\
\hline
\end{tabular}




\section{ACCEPTED MANUSCRIPT}

\begin{tabular}{|l|l|l|l|l|l|l|l|l|}
\hline 14 & Libya & 3 & 0 & 0.0 & 2 & 1 & 50.0 & 0.0 \\
\hline 15 & Malawi & 14 & 2 & 14.2 & 4 & 1 & 25.0 & 50.0 \\
\hline 16 & Rwanda & 9 & 2 & 22.2 & 3 & 1 & 33.3 & 50.0 \\
\hline 17 & Sierra & 2 & 2 & 100 & 1 & 1 & 100 & 50.0 \\
\hline 18 & Leone & & & & & & & \\
\hline 19 & Zambia & 15 & 3 & 20.0 & 2 & 1 & 50.0 & 33.3 \\
\hline 20 & Zimbabwe & 37 & 4 & 10.8 & 12 & 1 & 8.3 & 25.0 \\
\hline & Total & 1992 & 479 & 24.1 & 486 & 145 & 29.8 & 30.3 \\
\hline
\end{tabular}




\section{ACCEPTED MANUSCRIPT}

Table 2. Comparative performance of the journals in major indexing databases.

\begin{tabular}{|c|c|c|c|c|c|c|c|c|c|c|c|}
\hline & & & Goog & Schola & & Web c & Sciel & & Scopu & & \\
\hline $\begin{array}{l}\mathrm{S} / \\
\mathrm{N}\end{array}$ & Journal & $\begin{array}{l}\text { Countr } \\
\mathrm{y}\end{array}$ & $\begin{array}{l}\text { Total } \\
\text { Paper } \\
\text { S }\end{array}$ & $\begin{array}{l}\text { Total } \\
\text { Cites }\end{array}$ & $\begin{array}{l}\mathrm{h}- \\
\text { inde } \\
\mathrm{x}\end{array}$ & $\begin{array}{l}\text { Total } \\
\text { Paper } \\
\text { S }\end{array}$ & $\begin{array}{l}\text { Tota } \\
1 \\
\text { Cite }\end{array}$ & JIF* & $\begin{array}{l}\text { Total } \\
\text { paper } \\
\text { s }\end{array}$ & $\begin{array}{l}\text { Total } \\
\text { Cites }\end{array}$ & $\begin{array}{l}\text { SNI } \\
\mathrm{P}\end{array}$ \\
\hline 1 & $\begin{array}{l}\text { South } \\
\text { African } \\
\text { Medical } \\
\text { Journal }\end{array}$ & $\begin{array}{l}\text { South } \\
\text { Africa }\end{array}$ & 1835 & 5450 & 26 & 129 & $\begin{array}{l}301 \\
8\end{array}$ & $\begin{array}{l}0.56 \\
6\end{array}$ & 1613 & $\begin{array}{l}1830 \\
4\end{array}$ & $\begin{array}{l}0.64 \\
8\end{array}$ \\
\hline 3 & $\begin{array}{l}\text { Tropical } \\
\text { Journal of } \\
\text { Pharmaceutic } \\
\text { al Research }\end{array}$ & Nigeria & 804 & 2611 & 20 & 244 & 637 & $\begin{array}{l}0.58 \\
9\end{array}$ & 746 & 1732 & $\begin{array}{l}0.71 \\
1\end{array}$ \\
\hline 2 & $\begin{array}{l}\text { African } \\
\text { Health } \\
\text { Sciences }\end{array}$ & Uganda & 591 & 3348 & 20 & 150 & 871 & $\begin{array}{l}0.72 \\
2\end{array}$ & 627 & 3562 & $\begin{array}{l}0.82 \\
2\end{array}$ \\
\hline 4 & $\begin{array}{l}\text { African } \\
\text { Journal of } \\
\text { Traditional, } \\
\text { Complement } \\
\text { ary and }\end{array}$ & Nigeria & 580 & 2248 & 19 & 244 & 586 & $\begin{array}{l}0.50 \\
0\end{array}$ & 535 & 2678 & $\begin{array}{l}0.62 \\
1\end{array}$ \\
\hline
\end{tabular}




\section{ACCEPTED MANUSCRIPT}

\begin{tabular}{|c|c|c|c|c|c|c|c|c|c|c|c|}
\hline & $\begin{array}{l}\text { Alternative } \\
\text { Medicines }\end{array}$ & & & & & & & & & & \\
\hline 5 & $\begin{array}{l}\text { Pan African } \\
\text { Medical } \\
\text { Journal }\end{array}$ & Kenya & 2753 & 2957 & 18 & - & - & - & 2453 & 755 & $\begin{array}{l}0.22 \\
4\end{array}$ \\
\hline 6 & $\begin{array}{l}\text { Nigerian } \\
\text { Journal of } \\
\text { Clinical } \\
\text { Practice }\end{array}$ & Nigeria & 588 & 2437 & 17 & 156 & 377 & $\begin{array}{l}0.52 \\
7\end{array}$ & 609 & 1590 & $\begin{array}{l}0.76 \\
5\end{array}$ \\
\hline 7 & $\begin{array}{l}\text { African } \\
\text { Journal of } \\
\text { Reproductive } \\
\text { Health }\end{array}$ & Nigeria & 406 & 1672 & 16 & - & - & - & 343 & 2488 & $\begin{array}{l}0.25 \\
7\end{array}$ \\
\hline 8 & $\begin{array}{l}\text { Annals of } \\
\text { African } \\
\text { Medicine }\end{array}$ & Nigeria & 290 & 1244 & 15 & & & & 285 & 1246 & $\begin{array}{l}0.92 \\
4\end{array}$ \\
\hline 9 & $\begin{array}{l}\text { Ghana } \\
\text { Medical } \\
\text { Journal }\end{array}$ & Ghana & 205 & 992 & 15 & - & - & - & 130 & 192 & $\begin{array}{l}0.36 \\
9\end{array}$ \\
\hline 10 & $\begin{array}{l}\text { Ethiopian } \\
\text { Journal of } \\
\text { Health }\end{array}$ & $\begin{array}{l}\text { Ethiopi } \\
\text { a }\end{array}$ & 211 & 948 & 15 & - & - & - & 82 & 19 & $\begin{array}{l}0.18 \\
5\end{array}$ \\
\hline
\end{tabular}




\section{ACCEPTED MANUSCRIPT}

\begin{tabular}{|c|c|c|c|c|c|c|c|c|c|c|c|}
\hline & Sciences & & & & & & & & & & \\
\hline 11 & $\begin{array}{l}\text { African } \\
\text { Journal of } \\
\text { AIDS } \\
\text { Research }\end{array}$ & $\begin{array}{l}\text { South } \\
\text { Africa }\end{array}$ & 207 & 814 & 13 & 41 & 307 & $\begin{array}{l}0.79 \\
0\end{array}$ & 183 & 1363 & $\begin{array}{l}0.44 \\
0\end{array}$ \\
\hline 12 & $\begin{array}{l}\text { Ethiopian } \\
\text { Journal of } \\
\text { Health } \\
\text { Development }\end{array}$ & $\begin{array}{l}\text { Ethiopi } \\
\text { a }\end{array}$ & 188 & 660 & 13 & NA & 409 & $\begin{array}{l}0.12 \\
7\end{array}$ & 144 & 346 & $\begin{array}{l}0.90 \\
0\end{array}$ \\
\hline 14 & $\begin{array}{l}\text { African } \\
\text { Journal of } \\
\text { Paediatric } \\
\text { Surgery }\end{array}$ & Nigeria & 418 & 1095 & 12 & - & - & - & 412 & 529 & $\begin{array}{l}0.51 \\
1\end{array}$ \\
\hline 13 & $\begin{array}{l}\text { Journal of } \\
\text { Medicine and } \\
\text { Medical } \\
\text { Sciences }\end{array}$ & Nigeria & 867 & 1562 & 12 & - & - & - & 272 & 3004 & $\begin{array}{l}0.17 \\
1\end{array}$ \\
\hline 16 & $\begin{array}{l}\text { Libyan } \\
\text { Journal of } \\
\text { Medicine }\end{array}$ & Libya & 182 & 738 & 12 & 18 & 147 & $\begin{array}{l}1.05 \\
7\end{array}$ & 194 & 346 & $\begin{array}{l}0.49 \\
2\end{array}$ \\
\hline 17 & $\begin{array}{l}\text { South } \\
\text { African }\end{array}$ & $\begin{array}{l}\text { South } \\
\text { Africa }\end{array}$ & 200 & 537 & 12 & - & - & - & 193 & 538 & $\begin{array}{l}0.30 \\
2\end{array}$ \\
\hline
\end{tabular}




\section{ACCEPTED MANUSCRIPT}

\begin{tabular}{|c|c|c|c|c|c|c|c|c|c|c|c|}
\hline & $\begin{array}{l}\text { Journal of } \\
\text { Clinical } \\
\text { Nutrition }\end{array}$ & & & & & & & & & & \\
\hline 15 & $\begin{array}{l}\text { Annals of } \\
\text { Medical and } \\
\text { Health } \\
\text { Sciences } \\
\text { Research }\end{array}$ & Nigeria & 244 & 807 & 12 & - & - & - & & & $\mathrm{NI}$ \\
\hline 18 & $\begin{array}{l}\text { West African } \\
\text { Journal of } \\
\text { Medicine }\end{array}$ & Nigeria & 288 & 648 & 11 & - & - & - & 298 & 3103 & $\begin{array}{l}0.64 \\
5\end{array}$ \\
\hline 19 & $\begin{array}{l}\text { Tanzania } \\
\text { Journal of } \\
\text { Health } \\
\text { Research }\end{array}$ & $\begin{array}{l}\text { Tanzan } \\
\text { ia }\end{array}$ & 224 & 642 & 11 & - & - & - & 250 & 655 & $\begin{array}{l}0.18 \\
5\end{array}$ \\
\hline 21 & $\begin{array}{l}\text { Nigerian } \\
\text { Journal of } \\
\text { Medicine }\end{array}$ & Nigeria & 438 & 892 & 10 & - & - & - & 430 & 1758 & $\begin{array}{l}0.17 \\
1\end{array}$ \\
\hline 23 & $\begin{array}{l}\text { South } \\
\text { African } \\
\text { Journal of } \\
\text { Surgery }\end{array}$ & $\begin{array}{l}\text { South } \\
\text { Africa }\end{array}$ & 241 & 495 & 10 & 30 & 205 & $\begin{array}{l}0.39 \\
7\end{array}$ & 207 & 1216 & $\begin{array}{l}0.73 \\
9\end{array}$ \\
\hline
\end{tabular}




\section{ACCEPTED MANUSCRIPT}

\begin{tabular}{|c|c|c|c|c|c|c|c|c|c|c|c|}
\hline 22 & $\begin{array}{l}\text { Southern } \\
\text { African } \\
\text { Journal of } \\
\text { HIV } \\
\text { Medicine }\end{array}$ & $\begin{array}{l}\text { South } \\
\text { Africa }\end{array}$ & 180 & 524 & 10 & 33 & 106 & $\begin{array}{l}0.89 \\
8\end{array}$ & 182 & 513 & $\begin{array}{l}0.34 \\
1\end{array}$ \\
\hline 24 & $\begin{array}{l}\text { Malawi } \\
\text { Medical } \\
\text { Journal }\end{array}$ & Malawi & 287 & 444 & 10 & 24 & 104 & 0.38 & 182 & 224 & $\begin{array}{l}0.23 \\
7\end{array}$ \\
\hline 20 & $\begin{array}{l}\text { Nigerian } \\
\text { Medical } \\
\text { Journal }\end{array}$ & Nigeria & 363 & 943 & 10 & - & - & - & & NI & \\
\hline 25 & $\begin{array}{l}\text { Egyptian } \\
\text { Journal of } \\
\text { Medical } \\
\text { Human } \\
\text { Genetics }\end{array}$ & Egypt & 224 & 457 & 9 & - & - & - & 211 & 163 & $\begin{array}{l}0.52 \\
9\end{array}$ \\
\hline 26 & $\begin{array}{l}\text { African } \\
\text { Journal of } \\
\text { Biomedical } \\
\text { Research }\end{array}$ & Nigeria & & 371 & 9 & - & - & - & - & - & - \\
\hline 27 & $\begin{array}{l}\text { South } \\
\text { African }\end{array}$ & $\begin{array}{l}\text { South } \\
\text { Africa }\end{array}$ & 1748 & 1109 & 8 & - & - & - & 516 & 838 & $\begin{array}{l}0.18 \\
6\end{array}$ \\
\hline
\end{tabular}




\section{ACCEPTED MANUSCRIPT}

\begin{tabular}{|c|c|c|c|c|c|c|c|c|c|c|c|}
\hline & $\begin{array}{l}\text { Family } \\
\text { Practice }\end{array}$ & & & & & & & & & & \\
\hline 28 & $\begin{array}{l}\text { East African } \\
\text { Journal of } \\
\text { Public Health }\end{array}$ & $\begin{array}{l}\text { Tanzan } \\
\text { ia }\end{array}$ & 278 & 427 & 8 & - & - & - & 170 & 712 & $\begin{array}{l}0.21 \\
9\end{array}$ \\
\hline 29 & $\begin{array}{l}\text { Alexandria } \\
\text { Journal of } \\
\text { Medicine }\end{array}$ & Egypt & 262 & 373 & 8 & - & - & - & & & NA \\
\hline & Total & & $\begin{array}{l}15,37 \\
1\end{array}$ & $\begin{array}{l}37,44 \\
8\end{array}$ & & 1069 & $\begin{array}{l}6,66 \\
1\end{array}$ & & $\begin{array}{l}11,26 \\
7\end{array}$ & $\begin{array}{l}47,87 \\
4\end{array}$ & \\
\hline
\end{tabular}

JIF = Journal impact factor; SNIP = Source Normalised Impact per Paper

Figure 1. Percentage of AJOL journals in citation databases. 


\section{ACCEPTED MANUSCRIPT}

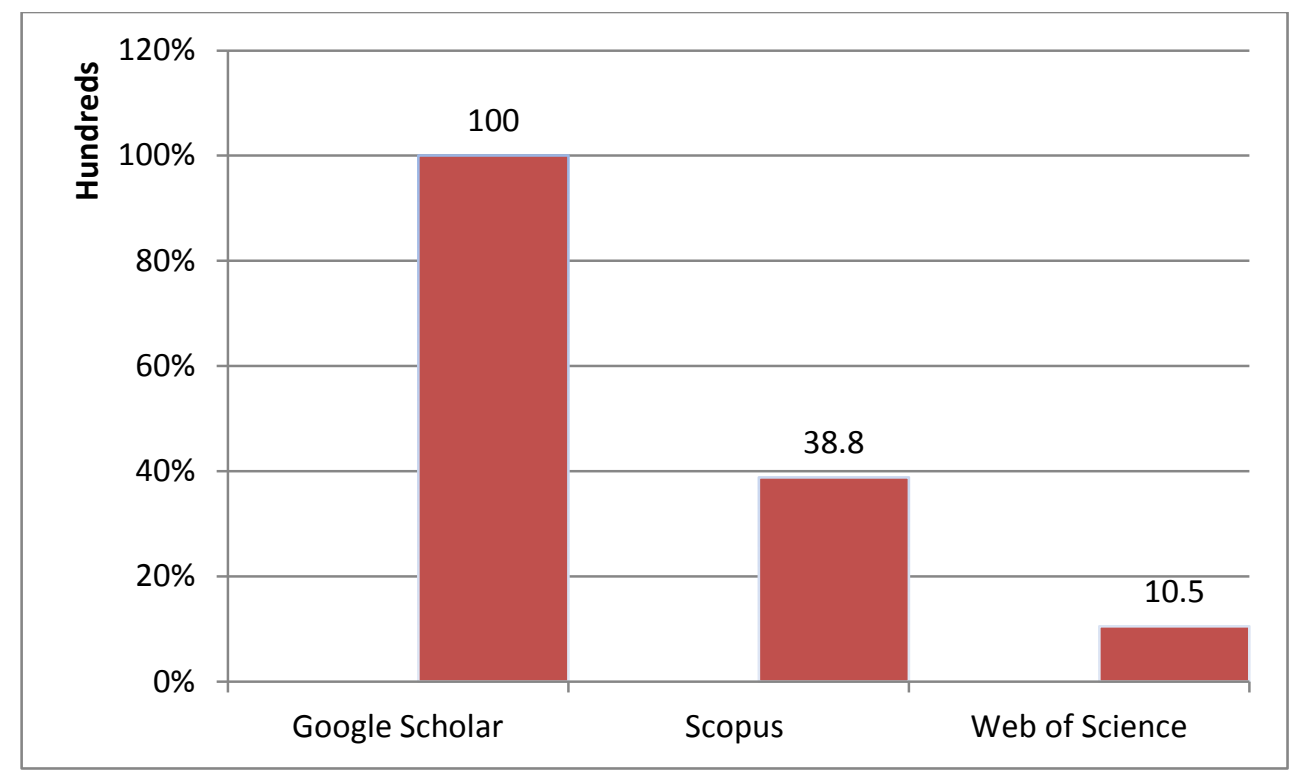

Figure 1. Percentage of AJOL journals in citation databases. 